\title{
Nature-based solutions for hydro-meteorological risk reduction: a state-of-the-art review of the research area
}

\author{
Laddaporn Ruangpan $^{1,2}$, Zoran Vojinovic ${ }^{1,3}$, Silvana Di Sabatino ${ }^{4}$, Laura Sandra Leo ${ }^{4}$, Vittoria Capobianco $^{5}$, \\ Amy M. P. Oen ${ }^{5}$, Michael E. McClain ${ }^{1,2}$, and Elena Lopez-Gunn ${ }^{6}$ \\ ${ }^{1}$ IHE Delft Institute for Water Education, Delft, the Netherlands \\ ${ }^{2}$ Department of Water Management, Faculty of Civil Engineering and Geosciences, \\ Delft University of Technology, Delft, the Netherlands \\ ${ }^{3}$ College for Engineering, Mathematics and Physical Sciences, University of Exeter, Exeter, UK \\ ${ }^{4}$ Department of Physics and Astronomy, University of Bologna, Bologna, Italy \\ ${ }^{5}$ Norwegian Geotechnical Institute, Oslo, Norway \\ ${ }^{6}$ Icatalist S.L., Madrid, Spain
}

Correspondence: Laddaporn Ruangpan (l.ruangpan@tudelft.nl)

Received: 16 April 2019 - Discussion started: 30 April 2019

Revised: 29 November 2019 - Accepted: 15 December 2019 - Published: 20 January 2020

\begin{abstract}
Hydro-meteorological risks due to natural hazards such as severe floods, storm surges, landslides and droughts are causing impacts on different sectors of society. Such risks are expected to become worse given projected changes in climate, degradation of ecosystems, population growth and urbanisation. In this respect, nature-based solutions (NBSs) have emerged as effective means to respond to such challenges. A NBS is a term used for innovative solutions that are based on natural processes and ecosystems to solve different types of societal and environmental challenges. The present paper provides a critical review of the literature concerning NBSs for hydro-meteorological risk reduction and identifies current knowledge gaps and future research prospects. There has been a considerable growth of scientific publications on this topic, with a more significant rise taking place from 2007 onwards. Hence, the review process presented in this paper starts by sourcing 1608 articles from Scopus and 1431 articles from the Web of Science. The full analysis was performed on 146 articles. The analysis confirmed that numerous advancements in the area of NBSs have been achieved to date. These solutions have already proven to be valuable in providing sustainable, cost-effective, multi-purpose and flexible means for hydro-meteorological risk reduction. However, there are still many areas where further research and demonstration are needed in order to promote their upscal-
\end{abstract}

ing and replication and to make them become mainstream solutions.

\section{Introduction}

There is increasing evidence that climate change and associated hydro-meteorological risk are already causing wideranging impacts on the global economy, human well-being and the environment. Floods, storm surges, landslides, avalanches, hail, windstorms, droughts, heat waves and forest fires are a few examples of hydro-meteorological hazards that pose a significant risk. Hydro-meteorological risk is the probability of damage due to hydro-meteorological hazards and its interplay with exposure and vulnerability of the affected humans and environments (Merz et al., 2010). Some of the main reasons for such risks are climate change, land use change, water use change and other pressures linked to population growth (Thorslund et al., 2017). The situation is likely to become worse given the projected changes in climate (see, for example, EEA, 2017). Therefore, effective climate change adaptation (CCA) and disaster risk reduction (DRR) strategies are needed to mitigate the risks of extreme events and to increase resilience to disasters, particularly among vulnerable populations (Maragno et al., 2018; McVittie et al., 2018). 
Since biodiversity and ecosystem services can play an important role in responding to climate-related challenges, both mitigation and adaptation strategies should take into consideration a variety of green infrastructure (GI) and ecosystembased adaptation (EbA) measures as effective means to respond to present and future disaster risk (see also EEA, 2015). Such approaches are already well accepted within multilateral frameworks such as the United Nations (UN) Framework Convention on Climate Change (UNFCCC), the Convention on Biological Diversity (CBD) and the Sendai Framework for Disaster Risk Reduction (SFDRR). As such, they are recognised as effective means for CCA and DRR and for the implementation of the Sustainable Development Goals (SDGs).

In view of the points above, many countries are nowadays developing adaptation and mitigation strategies based on GI and EbA to reduce their vulnerability to hydrometeorological hazards (Rangarajan et al., 2015; EEA, 2015). Nature-based solutions (NBSs) have been introduced relatively recently. The reason for their introduction is that NBSs offer the possibility to work closely with nature in adapting to future changes, reducing the impact of climate change and improving human well-being (Cohen-Shacham et al., 2016). NBSs have been the focus of research in several EU Horizon 2020-funded projects. Horizon 2020 offers new opportunities in the focus area of "Smart and Sustainable Cities with Nature based solutions" (Faivre et al., 2017). Some of these important projects are Nature4Cites, NATURVATION, NAIAD, BiodivERsA, INSPIRATION, URBAN GreenUP, UNaLaB, URBINAT, CLEVER Cities, proGIreg, EdiCitNet, Regenerating ECOsystems with Nature-based solutions for hydro-meteorological risk rEduCTion (RECONECT), OPERANDUM, ThinkNature, EKLIPSE and PHUSICOS (nature4cities, 2019). Through these projects, knowledge of NBSs has grown rapidly and been documented in a considerable body of grey literature (project reports, for example). On the other hand, the number of scientific studies focused on NBSs to reduce hydro-meteorological risk is continuously increasing all over the world.

The aim of this article is to provide a state-of-the-art review of scientific publications on hydro-meteorological risk reduction with NBSs to indicate some directions for future research based on the current knowledge gaps. The analysis focuses on the following hydro-meteorological hazards: floods, droughts, storm surges and landslides. The review addresses both small- and large-scale interventions and explores available techniques, methods and tools for NBS assessment while also providing a snapshot of the major socioeconomic factors at play in the implementation process. The key objectives and methods of this study are discussed in Sect. 3, while Sect. 2 provides a brief overview of concepts and definitions related to NBSs either in general or that are specifically linked to hydro-meteorological risk reduction. Results and conclusions are discussed in Sects. 4 and 5 respectively.

\section{Overview of definitions and theoretical backgrounds}

There are several terms and concepts which have been used interchangeably in the literature to date. In terms of the NBSs, the two most prominent definitions are from the International Union for Conservation of Nature (IUCN) and the European Commission. The European Commission defines nature-based solutions as "Solutions that aim to help societies address a variety of environmental, social and economic challenges in sustainable ways. They are actions inspired by, supported by or copied from nature, both using and enhancing existing solutions to challenges as well as exploring more novel solutions. Nature-based solutions use the features and complex system processes of nature, such as its ability to store carbon and regulate water flows, in order to achieve desired outcomes, such as reduced disaster risk and an environment that improves human well-being and socially inclusive green growth" (EC, 2015). The IUCN has proposed a definition of NBSs as "actions to protect, sustainably manage and restore natural and modified ecosystems that address societal challenges effectively and adaptively, simultaneously providing human well-being and biodiversity benefits" (CohenShacham et al., 2016). Eggermont et al. (2015) proposed a typology characterising NBSs into three types: (i) NBSs that address a better use of natural or protected ecosystems (no or minimal intervention), which fits with how the IUCN frames NBSs, (ii) NBSs for sustainability and multi-functionality of managed ecosystems, and (iii) NBSs for the design and the management of new ecosystems, which is more representative of the definition given by the European Commission.

A NBS is a collective term for innovative solutions to solve different types of societal and environmental challenges, based on natural processes and ecosystems. Therefore, it is considered to be an "umbrella concept" covering a range of different ecosystem-related approaches and linked concepts (Cohen-Shacham et al., 2016; Nesshöver et al., 2017) that provides an integrated way to look at different issues simultaneously. Due to the diverse policy origins, NBS terminology has evolved in the literature to emphasise different aspects of natural processes or functions. In this regard, nine different terms are commonly used in the scientific literature in the context of hydro-meteorological risk reduction: low-impact developments (LIDs), best management practices (BMPs), water-sensitive urban design (WSUD), sustainable urban drainage systems ( $\mathrm{SuDs}$ ), green infrastructure (GI), blue-green infrastructure (BGI), ecosystem-based adaptation $(\mathrm{EbA})$ and ecosystem-based disaster risk reduction (Eco-DRR). The timeline of each term based on their appearance in literature is shown in Fig. 1, and their definitions are given in Table 1. 


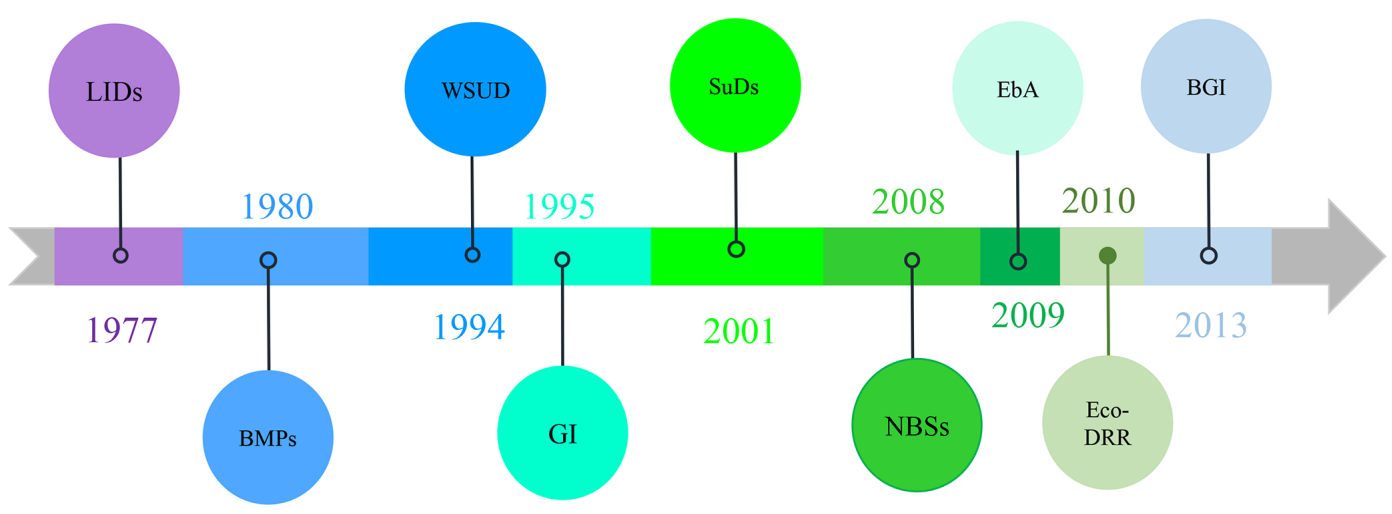

Figure 1. Timeline and year of origin of each term (low-impact developments - LIDs, best management practices - BMPs, water-sensitive urban design - WSUD, green infrastructure - GI, sustainable urban drainage systems - SuDs, nature-based solutions - NBSs, ecosystem-based adaptation - EbA, ecosystem-based disaster risk reduction - Eco-DRR - and blue-green infrastructure - BGI) based on their appearance in publications.

Table 1. Glossary of terms and their geographical usage.

\begin{tabular}{|c|c|c|c|}
\hline Terminology & Definition, objectives and purpose & Places where commonly used & Reference \\
\hline $\begin{array}{l}\text { Low-impact } \\
\text { development (LIDs) }\end{array}$ & $\begin{array}{l}\text { "LID is used as a retro- fit designed to reduce the stress on urban } \\
\text { stormwater infrastructure and/or create the resiliency to adapt to climate } \\
\text { changes, LID relies heavily on infiltration and evapotranspiration and } \\
\text { attempts to incorporate natural features into design." }\end{array}$ & $\begin{array}{l}\text { - US } \\
\text { - New Zealand }\end{array}$ & $\begin{array}{l}\text { Eckart et al. } \\
(2017)\end{array}$ \\
\hline $\begin{array}{l}\text { Best management } \\
\text { practices (BMPs) }\end{array}$ & $\begin{array}{l}\text { "A device, practice or method for removing, reducing, retarding or } \\
\text { preventing targeted stormwater run-off constituents, pollutants and } \\
\text { contaminants from reaching receiving waters." }\end{array}$ & $\begin{array}{l}\text { - US } \\
\text { - Canada }\end{array}$ & $\begin{array}{l}\text { Strecker et } \\
\text { al. }(2001)\end{array}$ \\
\hline $\begin{array}{l}\text { Water-sensitive } \\
\text { urban design } \\
\text { (WSUD) }\end{array}$ & $\begin{array}{l}\text { "Manage the water balance, maintain and where possible enhance water } \\
\text { quality, encourage water conservation and maintain water-related } \\
\text { environmental and recreational opportunities." }\end{array}$ & - Australia & $\begin{array}{l}\text { Whelans } \\
\text { consultants et } \\
\text { al. (1994) }\end{array}$ \\
\hline $\begin{array}{l}\text { Sustainable urban } \\
\text { drainage systems } \\
\text { (SuDs) }\end{array}$ & $\begin{array}{l}\text { "Replicate the natural drainage processes of an area - typically through } \\
\text { the use of vegetation-based interventions such as swales, water gardens } \\
\text { and green roofs, which increase localised infiltration, attenuation and/or } \\
\text { detention of stormwater." }\end{array}$ & $-\mathrm{UK}$ & $\begin{array}{l}\text { Ossa-Moreno } \\
\text { et al. } \\
(2017)\end{array}$ \\
\hline $\begin{array}{l}\text { Green infrastructure } \\
\text { (GI) }\end{array}$ & $\begin{array}{l}\text { "The network of natural and semi-natural areas, features and green } \\
\text { spaces in rural and urban, and terrestrial, freshwater, coastal and marine } \\
\text { areas, which together enhance ecosystem health and resilience, contribute } \\
\text { to biodiversity conservation and benefit human populations through the } \\
\text { maintenance and enhancement of ecosystem services." }\end{array}$ & $\begin{array}{l}\text { - US } \\
\text { - UK }\end{array}$ & $\begin{array}{l}\text { Naumann et } \\
\text { al. (2011) }\end{array}$ \\
\hline $\begin{array}{l}\text { Ecosystem-based } \\
\text { adaptation (EbA) }\end{array}$ & $\begin{array}{l}\text { "The use of biodiversity and ecosystem services as part of an overall } \\
\text { adaptation strategy to help people to adapt to the adverse effects of climate } \\
\text { change." }\end{array}$ & $\begin{array}{l}\text { - Canada } \\
\text { - Europe }\end{array}$ & CBD (2009) \\
\hline $\begin{array}{l}\text { Ecosystem-based } \\
\text { disaster risk reduction } \\
\text { (Eco-DRR) }\end{array}$ & $\begin{array}{l}\text { "The sustainable management, conservation, and restoration of } \\
\text { ecosystems to reduce disaster risk, with the aim of achieving sustainable } \\
\text { and resilient development." }\end{array}$ & $\begin{array}{l}\text { - Europe } \\
\text { - US }\end{array}$ & $\begin{array}{l}\text { Estrella and } \\
\text { Saalismaa } \\
(2013)\end{array}$ \\
\hline $\begin{array}{l}\text { Blue-green } \\
\text { infrastructure (BGI) }\end{array}$ & $\begin{array}{l}\text { "BGI provides a range of services that include; water supply, climate } \\
\text { regulation, pollution control and hazard regulation (blue services/goods), } \\
\text { crops, food and timber, wild species diversity, detoxification, cultural } \\
\text { services (physical health, aesthetics, spiritual), plus abilities to adapt to } \\
\text { and mitigate climate change." }\end{array}$ & - UK & $\begin{array}{l}\text { Lawson et } \\
\text { al. (2014) }\end{array}$ \\
\hline $\begin{array}{l}\text { Nature-based } \\
\text { solution }\end{array}$ & $\begin{array}{l}\text { "NBS aim to help societies address a variety of environmental, social and } \\
\text { economic challenges in sustainable ways. They are actions inspired by, } \\
\text { supported by or copied from nature, both using and enhancing existing } \\
\text { solutions to challenges as well as exploring more novel solutions." }\end{array}$ & - Europe & EC (2015) \\
\hline
\end{tabular}


The commonalities between a NBS and its sister concepts (i.e. GI, BGI, EbA and Eco-DRR) are that they take participatory, holistic, integrated approaches, using nature to enhance adaptive capacity, reduce hydro-meteorological risk, increase resilience, improve water quality, increase the opportunities for recreation, improve human well-being and health, enhance vegetation growth, and connect habitat and biodiversity. More information on the history, scope, application and underlying principle of terms of SuDs, LIDs, BMPs, WSUD and GI can be found in Fletcher et al. (2015), while the relationship between a NBS, GI-BGI and EbA is described in detail by Nesshöver et al. (2017).

Although all terms are based on a common idea, which is embedded in the umbrella concept of NBSs, differences in definition reflect their historical perspectives and knowledge base that were relevant at the time of the research (Fletcher et al., 2015). The distinguishing characteristic between a NBS and its sister concepts is how they address social, economic and environmental challenges (Faivre et al., 2018). Some terms such as SuDs, LIDs and WSUD refer to NBSs that specifically address stormwater management. They use the landscape feature to transform the linear approach of conventional stormwater management into a more cyclic approach where drainage, water supply and ecosystems are treated as part of the same system, mimicking more natural water flows (Liu and Jensen, 2018). GI and BGI focus more on technology-based infrastructures by applying natural alternatives (Nesshöver et al., 2017) for solving a specific activity (i.e. urban planning or stormwater). EbA looks at long-term changes within the conservation of biodiversity, ecosystem services and climate change, while Eco-DRR is more focused on immediate and medium-term impacts from the risk of weather, climate and non-climate-related hazards. EbA is often seen as a subset of NBSs that is explicitly concerned with climate change adaptation through the use of nature (Kabisch et al., 2016). From the above discussion, it can be concluded that EbA, Eco-DRR and GI-BGI provide more specific solutions to more specific issues. One key distinction is that unlike the sister concepts, the concept of NBSs is more open to different interpretations, which can be useful in encouraging stakeholders to take part in the discussion. Moreover, features of NBSs provide an alternative to working with existing measures or grey infrastructures. Therefore, it is important to note that very often a combination between natural and traditional engineering solutions (also known as "hybrid" solutions) is likely to produce more effective results than any of these measures alone, especially when their cobenefits are taken into consideration (Alves et al., 2019).

An important advancement in the science and practice of NBSs is given by the EKLIPSE Expert Working Group, which developed the first version of a multi-dimensional impact evaluation framework to support planning and evaluation of NBS projects. The document includes a list of impacts, indicators and methods for assessing the performance of NBSs in dealing with some major societal challenges
(EKLIPSE, 2017). Lafortezza et al. (2018) reviewed different case studies around the world where NBSs have been applied from the micro scale to the macro scale. Furthermore, an overview of how different NBS measures can regulate ecosystem services (i.e. soil protection, water quality, flood regulation and water provision) has been carried out by Keesstra et al. (2018).

\section{Materials and methodology}

The methodology consisted of two phases as schematised in Fig. 2. The first phase consisted of the identification of articles satisfying the search criteria discussed in Sect. 3.1. Next, all articles were screened and filtered based on the selection criteria discussed in Sect. 3.2.

\subsection{Search strategy}

The review analysis concerned articles from scientific journals written in English. Two main concepts were used in the search: nature-based solutions and hydro-meteorological risk reduction. As the concept of nature-based solutions appears under different names (which more or less relate to the same field of research), articles related to LIDs, BMPs, WSUD, SuDs, GI, BGI, EbA and Eco-DRR were included in the identification of relevant articles (see Table 2) The review of hydro-meteorological risk included literature on relevant terms (i.e. disasters, risks, hydrology, etc.) and different types of hazards (floods, droughts, storm surges and landslides; Table 2).

During the construction of the queries, the strings were searched only within index terms and metadata "titles, abstract, and keywords" in the Scopus database. The search terms for the two concepts were linked with the Boolean operator "AND", while the Boolean operator "OR" was used to link possible terms (Table 2). An example of a protocol is shown below:

"TITLE-ABS-KEY ("Nature-based Solutions" OR "Nature based solutions" OR "Nature Based Solutions" OR "nature-based solutions" OR "Low impact development" OR "Sustainable Urban Drainage Systems" OR "Water Sensitive Urban Design" OR "Best Management Practices" OR "Green infrastructure" OR "Green blue infrastructure" AND “flood”) AND (LIMIT-TO (DOCTYPE, “ar”) OR LIMITTO (DOCTYPE, “ch”) OR LIMIT-TO (DOCTYPE, “re”) OR LIMIT-TO (DOCTYPE, "bk”)) AND (LIMIT-TO (LANGUAGE, "English"))".

The time window selected for the review process was from 1 January 2007 to 19 November 2019; 1608 articles published in scientific journals were found in the Scopus database, and 1431 were found in the Web of Science database. The articles from both databases were combined for a total of 3089 articles. Duplicate articles were removed, 


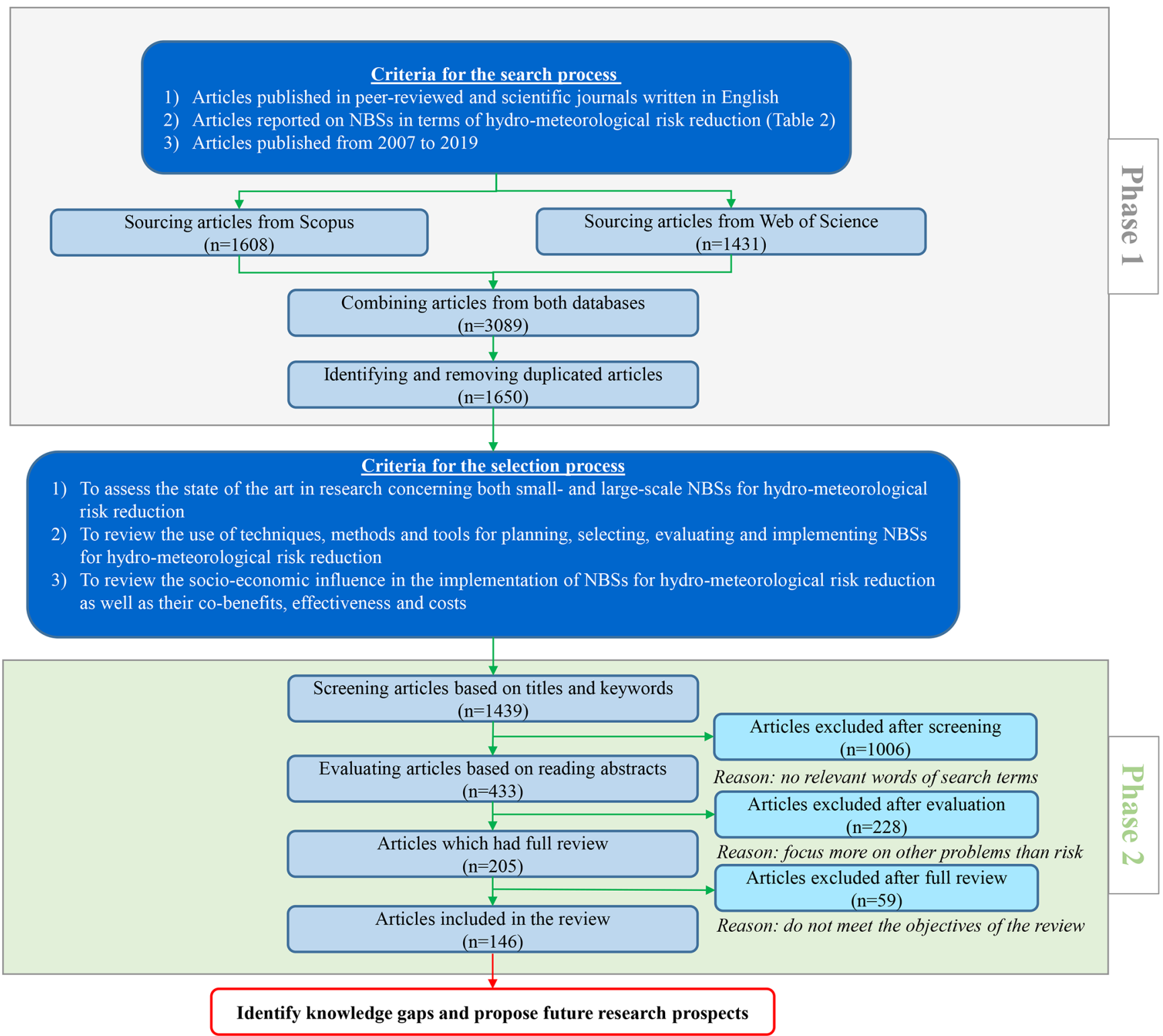

Figure 2. Process of article selection with systematic review method on nature-based solutions for hydro-meteorological risk reduction. The final number of fully reviewed articles is 146 .

resulting in a total of 1439 articles to be considered for further evaluation.

\subsection{Selection process}

As stated in the Introduction, this study aims at reviewing the state of the art of the research on NBSs that specifically address hydro-meteorological risk reduction. In this regard, the key objectives of the present review work were carefully formulated as follows:

1. to assess the state of the art in research concerning both small- and large-scale NBSs for hydro-meteorological risk reduction;
2. to review the use of techniques, methods and tools for planning, selecting, evaluating and implementing NBSs for hydro-meteorological risk reduction;

3. to review the socio-economic influence in the implementation of NBSs for hydro-meteorological risk reduction as well as their multiple benefits, co-benefits, effectiveness and costs;

4. to identify trends, knowledge gaps and proposed future research prospects with respect to the above three objectives. 
Table 2. Selected concepts and terms used to search relevant literature on NBSs for hydro-meteorological risk reduction.

\begin{tabular}{llll}
\hline \multirow{2}{*}{ No. } & \multicolumn{3}{c}{ Research words } \\
\cline { 2 - 4 } & $\begin{array}{l}\text { First concept } \\
\text { (nature-based solutions) }\end{array}$ & Connection & $\begin{array}{l}\text { Second concept } \\
\text { (hydro-meteorological risk) }\end{array}$ \\
\hline 1 & "Nature-based solutions" OR & AND & "Flood" \\
2 & "Nature-Based Solutions" OR & AND & "Drought" \\
3 & "Low impact development" OR & AND & "Storm surge" \\
4 & "Sustainable Urban Drainage Systems" OR & AND & "Landslide" \\
5 & "Water Sensitive Urban Design" OR & AND & "Hydro-meteorological" \\
6 & "Best Management Practices" OR & AND & "Disaster" \\
7 & "Green infrastructure" OR & AND & "Review" \\
8 & "Green blue infrastructure" OR & AND & "Hydrology" \\
9 & "Ecosystem-based Adaptation " OR & AND & "Coastal" \\
10 & "Ecosystem-based disaster risk reduction" OR & AND & "Risk" \\
11 & "Green and grey infrastructure" & & \\
\hline
\end{tabular}

These key objectives were defined for the review, with the intention that the results could be both quantitative and qualitative.

The 1439 articles resulting from the search query were thus evaluated with respect to these objectives and those found of little or no relevance with the topic removed. This selection process involved a set of progressive steps as schematised in Fig. 2. Initially, all articles were analysed on the basis of reading titles and keywords and evaluating their relation to the search terms. Articles were discarded if their title and keywords were considered to be of little or no relevance to the key objectives. This step served to reduce the number of articles from 1439 to 433. Secondly, a more in-depth analysis was conducted, based on reading the abstract of each article selected in the previous step. The criteria at this step was that the abstract should discuss hydrometeorological risk reduction. For example, if the abstract focused more on water quality than risk, that paper was excluded. This step served to reduce the number of articles from 433 to 205 . Finally, articles were read in full to identify those that were relevant to the review objectives. Any studies appearing to meet the key objectives (dealing with subjects such as effectiveness of NBSs, techniques, method and tools for planning, and other subjects relevant to the key objectives) were included in the review. As a result, the entire selection process resulted in a total of 146 articles relevant to the objectives of the present review.

\section{Findings}

\subsection{Lesson from research on small- and large-scale NBSs for hydro-meteorological risk reduction}

In this review, NBSs for hydro-meteorological risk reduction have been divided into small- and large-scale solutions (Fig. 3). Small-scale NBSs are usually referred to as NBSs at the urban or local scale (i.e. buildings, streets, roofs or houses), while NBSs in rural areas, river basins and at the regional scale are referred to as large-scale NBSs (Fig. 3).

\subsubsection{Research on small-scale NBSs for hydro-meteorological risk reduction}

Small-scale NBSs are usually applied to a specific location such as a single building or a street. However, for some cases, a single NBS is not sufficient to control a large amount of run-off. Therefore, this review discusses the application and effectiveness of both individual NBSs and multiple-NBS combinations. There are 41 articles that have been reviewed on the effectiveness of small-scale NBSs (Table 3). A majority of these (31 articles) discuss the effectiveness of a single or individual NBS site, while only 13 articles discuss the effectiveness of multiple-NBS sites (around $31 \%$ ). A summary of the effectiveness, co-benefits and cost of NBS measures at small scale is shown in Table 3 .

To date, various types of single-NBS sites have been studied with objectives such as reduction of the flood peak (Carpenter and Kaluvakolanu, 2011; Ercolani et al., 2018; Liao et al., 2015; Mei et al., 2018; Yang et al., 2018), delay and attenuation of the flood peak (Ishimatsu et al., 2017), reduction of volume of combined sewer overflows (Burszta-Adamiak and Mrowiec, 2013), and reduction of surface run-off volume (Lee et al., 2013; Shafique and Kim, 2018). The review found just three articles that discuss the reduction of drought risk by using NBSs. Lottering et al. (2015) used NBSs to reduce water consumption in suburban areas, while Radonic (2019) showed that rainwater harvesting can help reduce household water consumption. Finally, Wang et al. (2019) demonstrated that forests can significantly mitigate drought impacts and protect water supplies for crop irrigation.

The most common NBS measures in urban areas appear to be intensive green roofs (Burszta-Adamiak and Mrowiec, 2013; Carpenter and Kaluvakolanu, 2011; Ercolani et al., 


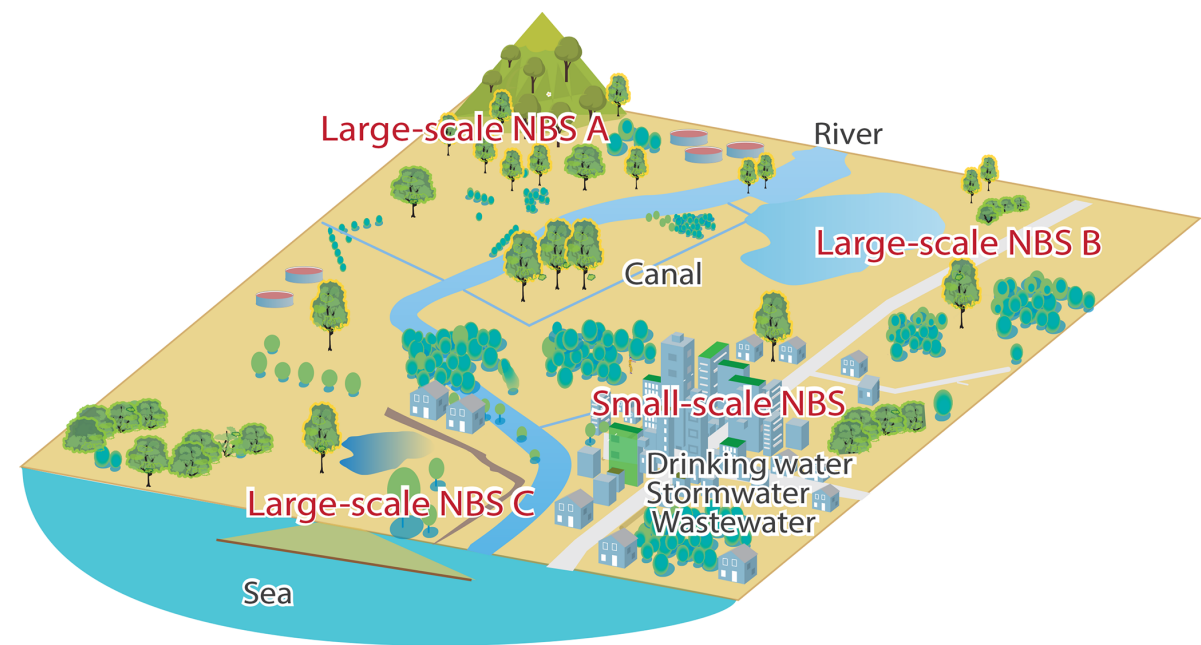

Figure 3. Illustration of large and small-scale nature-based solutions (NBSs). Large-scale NBS A illustrates NBSs in mountainous regions (e.g. afforestation, slope stabilisation, etc.), large-scale NBS B illustrates NBSs along river corridors (e.g. widening river, retention basins, etc.) and large-scale NBS C illustrates NBSs in coastal regions (e.g. sand dunes, protection dikes and walls, etc.). Typical examples of small-scale NBSs are green roofs, green walls, rain gardens, permeable pavements, swales, bio-retention, etc.

2018), extensive green roofs (Cipolla et al., 2016; Lee et al., 2013), rain gardens (Ishimatsu et al., 2017), rainwater harvesting (Khastagir and Jayasuriya, 2010), dry detention ponds (Liew et al., 2012), permeable pavements (Shafique et al., 2018), bio-retention (Khan et al., 2013; Olszewski and Allen, 2013), vegetated swales (Woznicki et al., 2018) and trees (Mills et al., 2016). However, the authors of these studies investigated the performance of such measures individually (i.e. at the specific, local and single site) without evaluating them in combination with other NBS sites or in hybrid combinations.

The literature to date acknowledges that the effectiveness of NBSs greatly depends on the magnitude and frequency of rainfall events. Green roofs are recognised in reducing peak flows more effectively for smaller-magnitude frequent storms than for larger-magnitude infrequent storms (see, for example, Ercolani et al., 2018). There are also reports that rain gardens are more effective in dealing with small discharges of rainwater (Ishimatsu et al., 2017). Swales and permeable pavements are more effective for flood reduction during heavier and shorter rainfall events. Zölch et al. (2017) suggested that the effectiveness of NBSs should be directly linked to their ability to increase (as much as possible) the storage capacities within the area of interest while using open spaces that have not been used previously and/or while providing benefits to other areas for urban planning.

Several studies evaluated the performance of multipleNBS (or combined-NBS) measures (i.e. a train of NBSs; see, for example, Damodaram et al., 2010; Dong et al., 2017; Huang et al., 2014; Luan et al., 2017). One of the most successful international projects in combining several NBS measures at the urban scale is the Sponge City Programme (SCP) in China. The SCP project was commissioned in 2014 with the aim of implementing both concepts and practices of LIDs and NBSs as well as various comprehensive urban water management strategies (Chan et al., 2018). Nowadays, the concept (Sponge City) is widely used when a city increases resilience to climate change. It also combines several systems, such as the source control system, urban drainage system and emergency discharge system.

Porous pavement appears to be one of the most popular measures suitable to be combined with other NBSs for urban run-off management. Examples of this are described in $\mathrm{Hu}$ et al. (2017), who used inundation modelling to evaluate the effectiveness of rainwater harvesting and pervious pavement as retrofitting technologies for flood inundation mitigation of an urbanised watershed. Damodaram et al. (2010) concluded that the combination of rainwater harvesting and permeable pavements is likely to be more effective than pond storage for small storms, while the pond is likely to be more effective to manage run-off from the more intense storms.

Several studies argue that multiple-NBS measures can lead to a more significant change in run-off regime and more effective long-term strategies than single-NBS measures (Webber et al., 2018). For example, Wu et al. (2018) simulated eight scenarios changing the percentage of combined green roof and permeable pavement in an urban setting. The results show that when green roofs and permeable pavements are applied at all possible locations, a $28 \%$ reduction in maximum inundation can be obtained. In comparison, scenarios implementing either green roofs or permeable pavements alone at all possible areas experienced a reduction of $14 \%$. One of the main reasons for the superior performance of combined NBSs is that they work in parallel, each treating a different portion of run-off generated from the sub-catchment (Pappalardo et al., 2017). For these combinations, the spatial dis- 


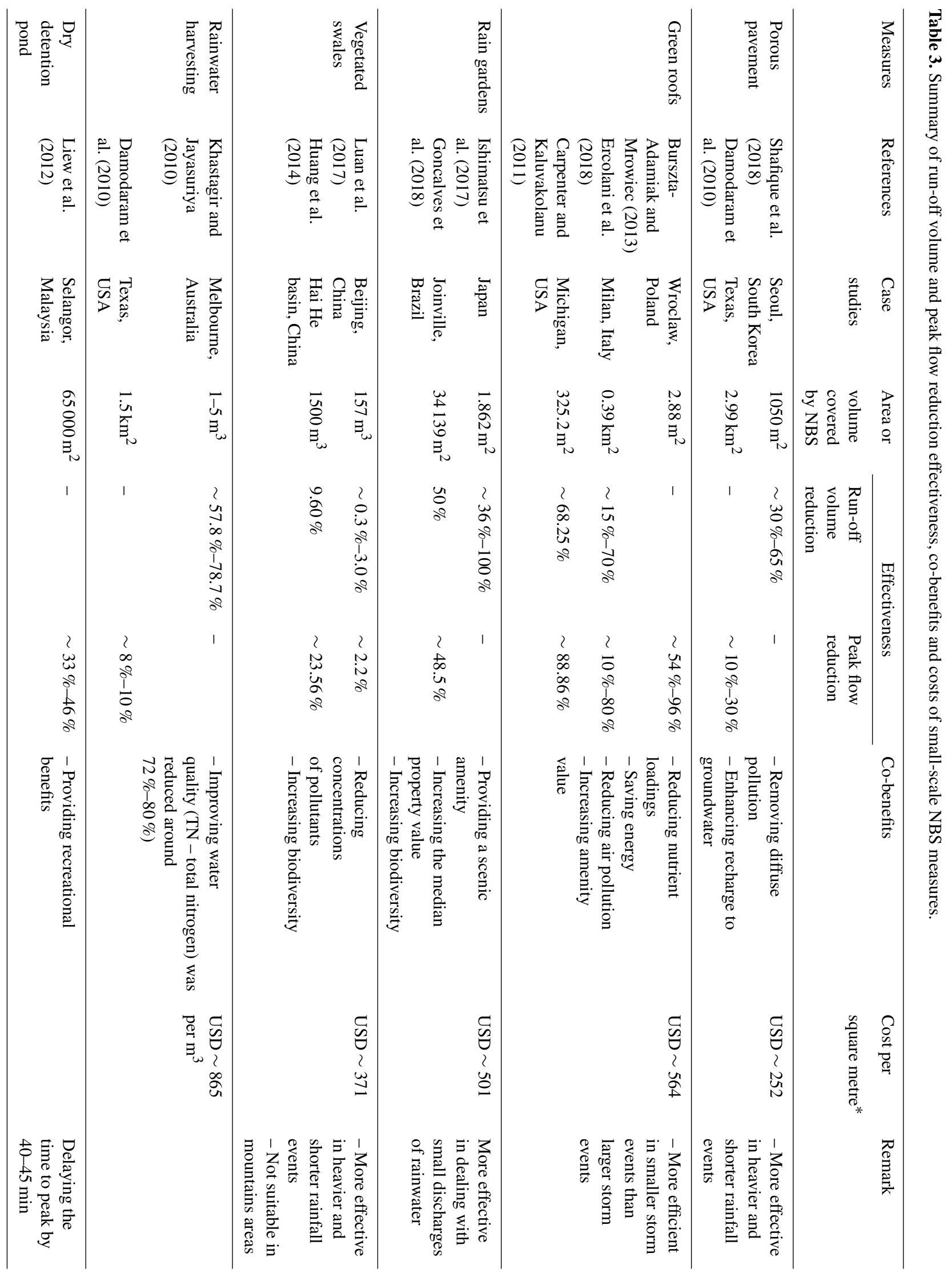




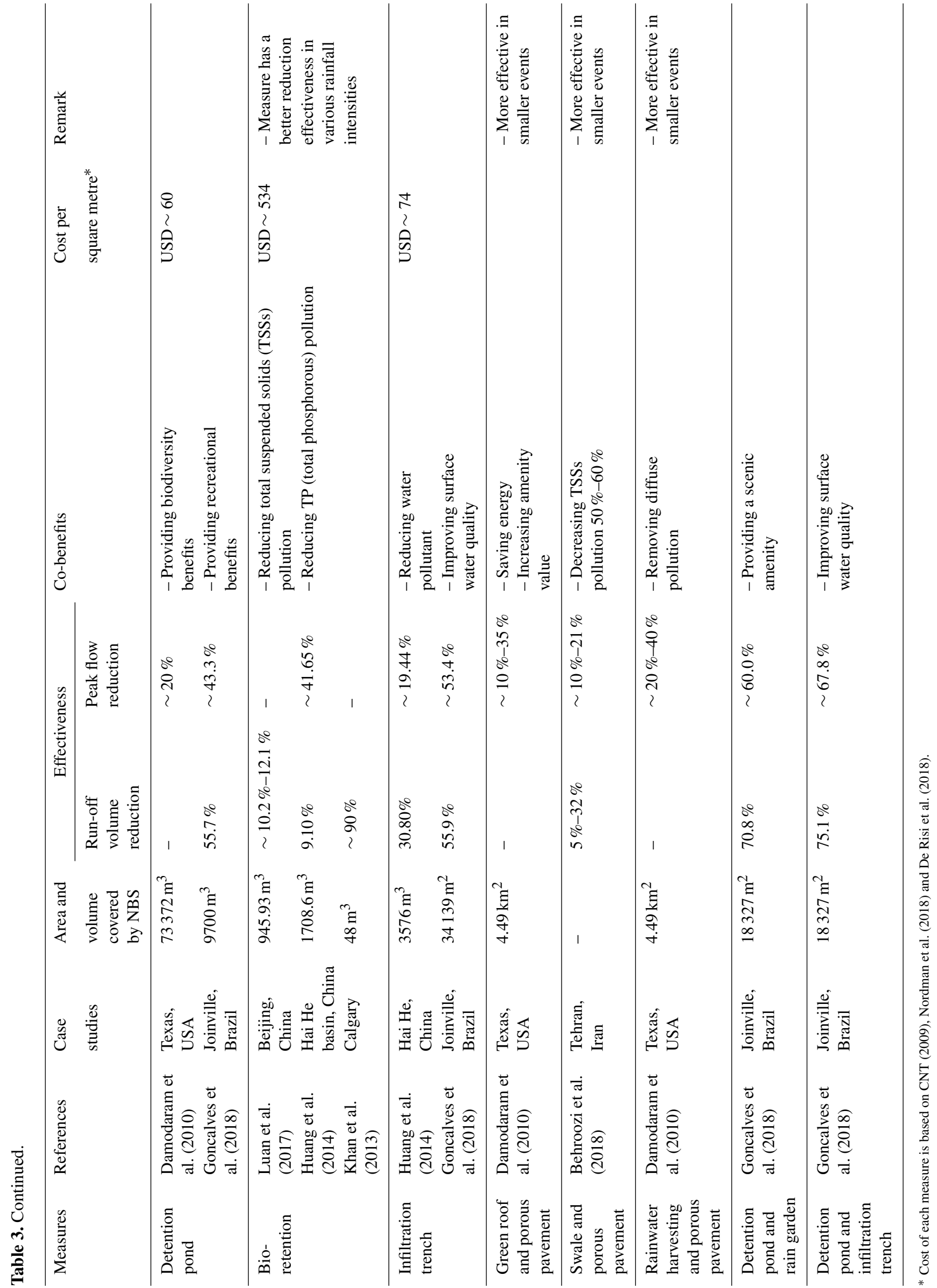


tribution should be carefully considered because it can improve the run-off regime better when compared to centralised NBSs (Loperfido et al., 2014).

Further research on the use of combined NBSs and grey infrastructure (i.e. hybrid measures) is desirable, as only three contributions were found in the review. Alves et al. (2016) presented a novel method to select, evaluate and place different hybrid measures for retrofitting urban drainage systems. However, only fundamental aspects were touched upon in the methodology, and they suggested that future work should include the possibility of considering stakeholders' preferences or flexibility within the method. In the work of Vojinovic et al. (2017), a methodological framework that combines ecosystem services (flood protection, education, art and culture, recreation, and tourism) with economic analysis for the selection of multi-functional measures and consideration of small- and large-scale NBSs has been discussed for the case of Ayutthaya in Thailand. Onuma and Tsuge (2018) compared the cost and benefits and performance of NBSs and grey infrastructures, concluding that NBSs are likely to be more effective when implemented through cooperation with local people, whereas hybrid solutions are more effective than a single NBS in terms of performance.

The first limitation of the above studies is that they only assess the effectiveness of NBSs at urban scales. This may not be sufficient for large events, as climate change is likely to increase the frequency and intensity of future events (Qin et al., 2013). A large-scale NBS could be a solution for storm events with large magnitude and long duration, which is usually the case for disaster risk reduction applications, and therefore research in this direction is highly desirable (Giacomoni et al., 2012). Although Fu et al. (2018) analysed variations in run-off for different scales and land-uses, the impact of NBSs was only examined for the small urban scale. Another limitation is that none of these contributions incorporated cost-benefit analyses (CBAs). CBAs can be used as a tool to support the decision-making process, as they serve the feasibility of implementation costs and the potential benefits of NBSs.

\subsubsection{Research on large-scale NBSs for hydro-meteorological risk reduction}

Large-scale water balance, water fluxes, water management and ecosystem services are affected by future changes such as climate change, land use changes, water use changes and population growth. To address such challenges, large-scale NBSs are needed to make more space for water to retain, decelerate, infiltrate, bypass and discharge (Cheng et al., 2017; Thorslund et al., 2017). Generally, a large-scale NBS combines different NBSs within a larger system to achieve better long-term strategies. There are some examples of NBS measures for hydro-meteorological risk reduction summarised in McVittie et al. (2018) and Sahani et al. (2019). A summary of effectiveness, co-benefits and cost of large-scale NBS measures is shown in Table 4.

Only few articles have addressed the combined behaviour of NBSs at large scales. One of the possible reasons is that large-scale systems are more complex than small-scale systems. The most common large-scale NBSs are flood storage basins (De Risi et al., 2018) and preservation and regeneration of forests in flood-prone areas (Bhattacharjee and Behera, 2018), making more room for the river (Klijn et al., 2013), river restoration (Chou, 2016), wetlands (Thorslund et al., 2017) and mountain forestation (Casteller et al., 2018).

A classic example of a large-scale NBS implementation is the Room for the River Programme implemented along the Rhine and Meuse rivers in the Netherlands. The Room for the River Programme consisted of 39 local projects based on nine different types of measures (Klijn et al., 2013). These measures are floodplain lowering, dike relocation, groyne lowering, summer bed deepening, water storage, bypassed and floodways, high-water channels, obstacle removal, and dike strengthening. The benefits that the programme achieved are more than just reducing flooding, also increasing opportunities for recreation, habitat and biodiversity in the area (Klijn et al., 2013). Another case study of a large-scale NBS is the Laojie River project in Taoyuan in Taiwan. The study focused on changing the channelised, culverted, flood-control watercourse into an accessible green infrastructure corridor for the public (Chou, 2016). The landscape changes resulting from this project have increased recreation activities and improved the aesthetic value in the area.

NBSs may benefit people in coastal areas by reducing risk from storm surges, wave energy, coastal flooding and erosion, as documented by several authors (see, for example, Van Coppenolle, 2018; Joyce et al., 2017; Ruckelshaus et al., 2016; Sutton-Grier et al., 2018). NBSs for coastal areas can be implemented either at large or small scales. They include dunes, beaches, oyster and coral reefs, mangroves, seagrass beds, and marshes. These measures can also provide habitats for different species such as fish, birds and other wildlife (Ruckelshaus et al., 2016). Schoonees et al. (2019) provided lists of general recommendations, technical guidelines and policies, and design considerations for NBSs in coastal areas. However, only a few articles of the 146 reviewed focused on the potential benefits of NBSs in coastal areas.

Casteller et al. (2018) concluded that native mountain forests could be used to reduce hydro-meteorological risk such as flash floods and landslides. Moreover, the use of NBSs in different forest ecosystems to reduce shallow landslide impacts should be addressed (de Jesús Arce-Mojica et al., 2019). To reduce the impact of large-scale hydrometeorological events, more research is needed on largescale NBSs and their hybrid combinations designed to attenuate flows and improve drainage. They should be implemented to include improvements in solid waste management, 
Table 4. Summary of effectiveness, co-benefits and costs of large-scale NBS measures.

\begin{tabular}{|c|c|c|c|c|c|c|}
\hline Measures & References & Case studies & $\begin{array}{l}\text { Area or volume } \\
\text { covered } \\
\text { by NBSs }\end{array}$ & Effectiveness & Co-benefits & Cost \\
\hline $\begin{array}{l}\text { De-culverting } \\
\text { (river } \\
\text { restoration) }\end{array}$ & Chou (2016) & $\begin{array}{l}\text { Laojie River, } \\
\text { Taiwan }\end{array}$ & $3 \mathrm{~km}$ & $\begin{array}{l}\text { - It can reduce flood } \\
\text { risk up to } 100 \text {-year } \\
\text { return period }\end{array}$ & $\begin{array}{l}\text { - Increasing landscape value } \\
\text { - Increasing recreational value }\end{array}$ & EUR $\sim 16.92$ million \\
\hline $\begin{array}{l}\text { Floodplain } \\
\text { lowering }\end{array}$ & $\begin{array}{l}\text { Klijn et al. } \\
(2013)\end{array}$ & $\begin{array}{l}\text { Deventer } \\
\text { Netherlands }\end{array}$ & $5.01 \mathrm{~km}^{2}$ & $\begin{array}{l}\text { - It can reduce water } \\
\text { level } 19 \mathrm{~cm}\end{array}$ & $\begin{array}{l}\text { - Increasing nature area } \\
\text { - Increasing agriculture value }\end{array}$ & EUR 136.7 million \\
\hline $\begin{array}{l}\text { Dike } \\
\text { relocation and } \\
\text { floodplain } \\
\text { lowering }\end{array}$ & $\begin{array}{l}\text { Klijn et al. } \\
(2013)\end{array}$ & $\begin{array}{l}\text { Nijmegen- } \\
\text { Lent, } \\
\text { Netherlands }\end{array}$ & $2.42 \mathrm{~km}^{2}$ & $\begin{array}{l}\text { - It can reduce water } \\
\text { level } 34 \mathrm{~cm}\end{array}$ & $\begin{array}{l}\text { - Increasing floodplain area } \\
\text { - Increasing recreational value }\end{array}$ & EUR $\sim 342.60$ million \\
\hline $\begin{array}{l}\text { Floodwater } \\
\text { storage }\end{array}$ & $\begin{array}{l}\text { Klijn et al. } \\
(2013)\end{array}$ & $\begin{array}{l}\text { Volkenrak- } \\
\text { Zoommeer, Netherlands }\end{array}$ & $200 \times 10^{6} \mathrm{~m}^{3}$ & $\begin{array}{l}\text { - It can reduce water } \\
\text { level } 50 \mathrm{~cm}\end{array}$ & $\begin{array}{l}\text { - Increasing habitat and } \\
\text { biodiversity in the area } \\
\text { - Increasing recreational value }\end{array}$ & EUR $\sim 386.20$ million \\
\hline $\begin{array}{l}\text { Green } \\
\text { floodway }\end{array}$ & $\begin{array}{l}\text { Klijn et al. } \\
(2013)\end{array}$ & $\begin{array}{l}\text { Veessen- } \\
\text { Wapenveld, Netherlands }\end{array}$ & $14.10 \mathrm{~km}^{2}$ & $\begin{array}{l}\text { - It can reduce water } \\
\text { level } 71 \mathrm{~cm}\end{array}$ & $\begin{array}{l}\text { - Increasing floodplain area } \\
\text { - Increasing recreational value }\end{array}$ & \\
\hline $\begin{array}{l}\text { Wetlands } \\
\text { (mangroves } \\
\text { and salt } \\
\text { marshes) }\end{array}$ & $\begin{array}{l}\text { Van Coppenolle } \\
(2018), \text { Gedan et } \\
\text { al. }(2011)\end{array}$ & & & $\begin{array}{l}\text { - It can mitigate } \\
\text { storm surge } 80 \% \\
\text { - It can protect } \\
\text { against tsunami } \\
\text { impacts }\end{array}$ & $\begin{array}{l}\text { - Providing shoreline protection } \\
\text { services }\end{array}$ & \\
\hline
\end{tabular}

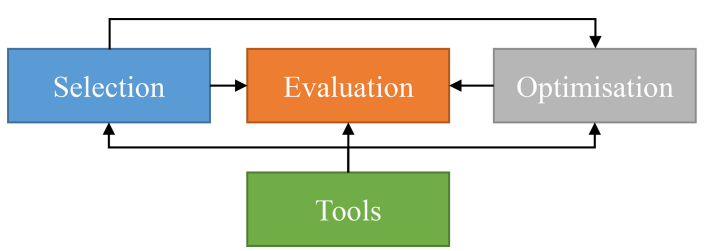

Figure 4. Evaluation process of nature-based solutions. The process includes selecting possible measures and evaluating and optimising measures' performance using available tools.

community-based river cleaning programmes and reforestation (De Risi et al., 2018).

\subsection{Techniques, methods and tools for planning, selecting, evaluating and implementing NBSs}

Figure 4 illustrates a typical process for the selection and evaluation of NBSs. The process starts by selecting possible measures that correspond to the local characteristics and project's target. The next step is concerned with evaluating the measures' performance using numerical models, costbenefit analysis and/or multi-criteria analysis. For more complex systems with a large number of scenarios and parameters, optimisation can be used to maximise the benefits and minimise the costs. The techniques, methods and tools for planning, selecting, evaluating and implementing NBSs are reviewed in the following section.

\subsubsection{Selection of NBSs}

It has been a well-accepted fact that not all NBSs are suitable for all conditions. Therefore, it is important to consider the feasibility and constraints at the site at an early stage in the selection process. The first consideration in selecting NBSs is to define the objective such as the target area (i.e. urban or rural) and performance requirements such as quantity and/or quality (Romnée and De Herde, 2015; Zhang and Chui, 2018). For example, Pappalardo et al. (2017) chose permeable pavements and green roofs because they can detain run-off or enhance infiltration to the subsoil. Another approach is to consider both primary benefits and key cobenefits. For instance, Majidi et al. (2019) developed a framework to select NBSs to reduce flood risk and enhance human thermal comfort (reducing heat stress). Many authors suggest restricting the choice of appropriate NBSs based on common site constraints such as land use, soil type, groundwater depth, catchment characteristics, political and financial regulations, amenities, environmental requirements, and space available (Eaton, 2018; Joyce et al., 2017; Nordman et al., 2018; Oraei Zare et al., 2012). For example, Eaton (2018) selected bio-retention measures because they are more suitable in low-density residential land use. Moreover, the study of Reynaud et al. (2017) describes how the type of NBS has an impact on individuals' preference for ecosystem services. Therefore, a screening analysis is necessary for selecting the NBS measures that are best suited to local constraints and objectives, providing decision makers with valuable information. The way forward in the selection of NBSs is to consider spatial planning principles to locate the position for 
measures. Spatial planning principles can facilitate and stimulate discussion among local communities, researchers, policymakers and government authorities.

\subsubsection{Frameworks and methods for evaluation of NBSs}

There are several frameworks and methods that can be used to evaluate the performance indicators of NBSs discussed in this review. One of the most popular evaluation approaches is to analyse, simulate and model hydrology, hydraulics and water balance processes. This information is then used to support decision makers, planners and stakeholders in their evaluation of performance and potential of NBSs by comparing modelled results against the current situation, baseline scenario or targets (Jia et al., 2015).

In addition to hydrological and hydraulic analyses, costbenefit analyses are often used to select and evaluate NBSs (Huang et al., 2018; Nordman et al., 2018; Watson et al., 2016; Webber et al., 2018). The common benefits considered include prevented damage costs, omitted infrastructures and prevented agricultural losses. One cost-benefit approach is to evaluate NBSs by applying the whole life cycle costing (LCC) approach, including construction, operation, maintenance and opportunity costs (Nordman et al., 2018), and return on investment (ROI; De Risi et al., 2018).

Another method for the evaluation of NBSs is multicriteria analysis (MCA), which has the potential to integrate and overcome the differences between social and technical approaches (Loc et al., 2017). It can be used to structure complex issues and help find a better understanding of costs and benefits. Such analysis is useful for decision makers when there are multiple and conflicting criteria to be considered (Alves et al., 2018b; Loos and Rogers, 2016). The MCA takes different criteria into account and assigns weights to each criterion. This process can produce a ranking of the different measures that can be implemented on the site (Chow et al., 2014; Jia et al., 2015). For example, Loc et al. (2017) integrated the results from numerical modelling and social surveys into a MCA and ranked the alternatives based on the evaluation criteria of flood mitigation, pollutant removal and aesthetics. Loos and Rogers (2016) applied multi-attribute utility theory (MAUT) to assess utility values for each alternative by assuming that preference and utility are independent of each other. Petit-Boix et al. (2017) recommended that future research combine the economic value of the predicted material and ecological damage, risk assessment models and environmental impacts of NBSs.

Since not all assessments can be done with modelling alone, interviews and fieldwork are often necessary. For instance, Chou (2016) used 18 open questions from six topics, namely accessibility, activities, public facilities, environmental quality, ecological value and flood prevention. These questions are used to evaluate the qualitative performance of river restoration. However, some of the methods are only appropriate for small-scale applications and cannot be applied in large catchments. Yang et al. (2018) proposed relative performance evaluation (RPE) methods, which use a score to calculate the performance for all alternatives. This score is calculated as the weighted sum of the scores of individual indicators.

From the discussion above, it can be observed that there are still challenges in evaluating intangible benefits of NBSs and incorporating stakeholders' preferences into the process. For complex systems with a large number of scenarios and parameters, simple trial-and-error methods may not be the feasible approach. In such cases, an automated optimisation method could be effectively applied to handle these tasks and to combine the above-mentioned methods. There is also a challenge in combining a range of aspects that can and cannot be expressed in monetary terms into the same framework of analysis.

\subsubsection{Optimal configuration of NBSs}

In order to implement NBSs, typical selection factors include the number of NBS measures, size, location and potential combinations of NBSs. Optimisation of NBS strategies has been increasingly used in the context of urban stormwater management. Most of the studies focus on minimising water quantity and improving water quality by selecting the type, design, size and location of NBSs (Behroozi et al., 2018; Gao et al., 2015; Giacomoni and Joseph, 2017; Zhang and Chui, 2018). Zhang and Chui (2018) systematically reviewed optimisation models that have different structures, objectives and allocation components. This section reviews some examples of using optimisation to assess NBSs.

A comprehensive modelling system typically refers to an optimisation package tool that integrates an "easyto-use" user interface with physically based deterministic models. Examples include SUSTAIN (the System for Urban Stormwater Treatment and Analysis IntegratioN; Zhang and Chui, 2018) and best management practice decision support (BMPDSS; Gao et al., 2015). The SUSTAIN model was developed by the US Environmental Protection Agency (US EPA) and aims to provide decision makers with support in the process of selection and placement of NBS measures and to optimise the hydrological performance and cost-effectiveness of NBSs in the urban watershed (Leslie et al., 2009; C. Li et al., 2018). There are several studies that apply SUSTAIN with the aim of minimising the cost of NBSs for both run-off quantity (flow volume and peak flow) and run-off quality (pollutant removal; Gao et al., 2015; N. Li et al., 2018). It is, however, important to note that comprehensive modelling systems are not always easily modified to fit with the specific needs of users.

Another optimisation tool approach is integrated modelalgorithm tools, which combine numerical (hydrologicalhydrodynamic) models with optimisation algorithms. A popular optimisation method used to evaluate NBS performance is a multialgorithm, genetically adaptive multiobjec- 
tive (AMALGAM) method using the multilevel spatial optimisation (MLSOP) framework (Liu et al., 2016).

In the reviewed articles, the non-dominated sorting genetic algorithm II (NSGA-II) is used in most of the studies to date. Wang et al. (2015) concluded that NSGA-II is one of the most popular multiobjective evolutionary algorithms (MOEAs) despite limited parameter tuning features and generally outperformed the other MOEAs in relation to the set of solutions generated. There are several examples of the use of NSGA-II. Oraei Zare et al. (2012) minimised run-off quantity while maximising the improvement of water quality and maximising reliability. Karamouz and Nazif (2013) minimised the cost of flood damage while minimising NBS cost in order to improve system performance in dealing with the emerging future conditions under climate change. Yazdi and Salehi Neyshabouri (2014) optimised cost-effectiveness, which focused on land use change strategies including orchard, brush and seeding measures in different parts of the watershed. All of the above-mentioned studies coupled NSGA-II with the Storm Water Management Model (SWMM) developed by US EPA (Cipolla et al., 2016; J. Li et al., 2018; Mei et al., 2018; Tao et al., 2017; Wu et al., 2018; Yang et al., 2018; Zhu and Chen, 2017) to address the optimisation problems.

There are two different optimisation methods of particle swarm optimisation (PSO) which have been found in the course of this review. The modified particle swarm optimisation (MPSO) is used by Duan et al. (2016) to solve the multi-objective optimal (MOO) of the cost-effectiveness of NBS-based detention tank design. Similarly, Behroozi et al. (2018) used the multi-objective particle swarm optimisation (MOPSO) by coupling it with SWMM to optimise the peak flow and mean total suspended solid (TSS) concentration reduction by changing the combinations of NBSs.

Another algorithm that is used for optimising the performance of NBSs is simulated annealing (SA). SA is a general probability optimisation algorithm that applies thermodynamic theories in statistics. An example of a study with SA is given by Huang et al. (2018), who automatically linked SA with SWMM to maximise the cost and benefit for flood mitigation and layout design. The cost-benefit analysis is computed using annual cost, which includes both annual fixed cost and annual maintenance cost. Another study that applied SA is Chen et al. (2017), who combined SA with SWMM to locate NBSs in Hsinchu County in northern Taiwan by considering three objective functions. These were minimising depths, durations and the number of inundation points in the watershed.

It can be observed that most of the optimisation models to date (both the comprehensive modelling system and model algorithms) are coupled with SWMM for urban storm management. There is still a lack of research that uses optimisation to maximise the efficiency of NBSs on a large scale as well as combining other co-benefits in optimisation (Table 3). Furthermore, there is a lack of research that employs two-dimensional models in the optimisation analysis. This is particularly important when considering estimation of flood damages and other flood propagation-related impacts.

\subsubsection{Tools for selection, evaluation and operation of NBSs}

Recently, several selection and evaluation tools have been developed in order to assist stakeholders in screening, selecting and visualising NBS measures. Examples of webbased applications developed to screen urban NBS measures are the green-blue design tool (atelier GROENBLAUW, 2019), PEARL KB (PEARL, 2019), climate adaptation app (Bosch Slabbers et al., 2019) and Naturally Resilient Communities solutions (Naturally Resilient Communities, 2019). These web-based tools allow the user to filter NBSs in relation to their problem type, measure, land use, scale and location.

In addition to the above, there are also tools that combine both the selection and evaluation processes together to use as planning support systems tool. An example is the SuD selection and location (SUDSLOC) tool, which is a GIS tool linked to an integrated 1-D hydraulic sewer model and a 2-D surface model. UrbanBEATS (the Urban Biophysical Environments and Technologies Simulator) aims to support the planning and implementation of WSUD infrastructure in urban environments (Kuller et al., 2018). Other tools that can be used to select and evaluate potential NBS interventions are Long-Term Hydrologic Impact Assessment-Low Impact Development (L-THIA-LID; Ahiablame et al., 2012; Liu et al., 2015) and the GIS-based tool called the Adaptation Support Tool (AST; Voskamp and Van de Ven, 2015). Although these tools could be useful in assisting decision makers, some of them may not be suitable for every location and scale. For example, source data required into L-THIA-LID cover only the US, and QUADEAU (Romnée and De Herde, 2015) is only suitable for urban stormwater management on a publicspace scale.

In addition to the above, other models such as MIKE packages developed by DHI (Semadeni-Davies et al., 2008), the soil and water assessment tool (SWAT; Cheng et al., 2017), IHMORS (Herrera et al., 2017), and the urban water optioneering tool (UWOT; Rozos et al., 2013) can be effectively used in the analysis effectiveness of NBSs.

To date, very few tools have been developed to calculate multiple benefits of NBSs in monetary terms as well as to address their qualitative benefits. Some examples are the Benefits of SuDs Tool (BeST), which provides a structured approach to evaluating potential benefits of NBSs (Digman et al., 2017; Donnell et al., 2018; Fenner, 2017), and the MUSIC (Model for Urban Stormwater Improvement Conceptualization) tool, which is a conceptual planning and design tool that also contains a life cycle costing module for different NBSs that are implemented in Australia (Khastagir and Jayasuriya, 2010; Schubert et al., 2017). 
There are also other tools that can be used for modelling stormwater management options and/or to assess economic aspects of NBSs in urban areas. These are documented in the work of Jayasooriya and $\mathrm{Ng}$ (2014). However, most of these tools only focus on small-scale NBSs such as bio-retentions, pervious pavements, green roofs, swales, retention ponds, biofiltration and rainwater harvesting. There are only a few tools that can address river and coastal flood protection measures and droughts, while none of the tools can be used to reduce the risk from landslides and storm surges. A lack of information systems, information clusters, and platforms for information exchange between authorities and practitioners has been recognised by Kabisch et al. (2016).

There is also the need to explore the use of sensors, regulators, telemetry, and supervisory control and data acquisition (SCADA) systems for efficient and effective operation and real-time control of NBSs. Such configurations, which are based on the use of real-time control technology for operation of NBSs, can be referred to as SMART NBSs. The value of exploring SMART NBS configurations may be particularly beneficial for hybrid systems, where NBS sites need to be configured to work closely with different kinds of measures.

\subsection{Socio-economic influence on implementation of NBSs}

Investing in NBSs for hydro-meteorological risk reduction is essential to ensure the capability for future socio-economic development (Faivre et al., 2018). In this respect, the European Commission has been investing considerably in the research and innovation of NBSs or EbA, and some recent efforts have been placed on practical demonstration of NBSs for climate change adaptation and risk prevention (Faivre et al., 2017). The European Commission is dedicated to bringing about innovative "sciences-policy-society" mechanisms, open consultations and knowledge-exchange platforms to engage society in improving the condition for implementation of NBSs (Faivre et al., 2017). There are some inventories of web portals, networks and initiatives that address NBSs at European, national and sub-national levels (Table 6).

Denjean et al. (2017) noted that the people who propose NBSs are in many cases ecologists and biologists who have been trained within a very different scientific paradigm and thus speak a "different language" to the key decision makers, who are often civil and financial engineers, contractors and financing officers. Hence, this may limit the feasibility of implementation of NBSs.

Very few articles study actions or processes in relation to stakeholder participation. However, those that do so stress the importance of involving stakeholders in the evaluation and implementation of NBSs and the current practical limitations of implementing NBSs. One of the important reasons is to ensure that stakeholders and local government are fully aware of the multiple benefits of NBSs so that they can in- tegrate them better into planning for sustainable cities (Ishimatsu et al., 2017). For example, Liu and Jensen (2018) and Chou (2016) claim that the implementation of NBSs with visible benefits in the landscape and the liveability of the city (in terms of amenities, recreation, green growth and microclimate) can create positive attitudes among stakeholders towards applying NBSs. Moreover, as the implementation of NBSs is often a costly investment for local communities, and the facilities are expected to be in place for a decade, it is essential for stakeholders to know the effectiveness of NBSs (Semadeni-Davies et al., 2008). Involving the community with authorities in both the planning and implementing process can be a very useful strategy (Dalimunthe, 2018). In a case study of the Great Plains in the US, Vogel et al. (2015) addressed how local perceptions of NBS effectiveness and applicability limit its adoption. One of the factors was a lack of awareness of NBSs and support from stakeholders and authorities. Another case in Portland, Oregon, US, Thorne et al. (2018) concluded that the limited adoption of NBSs is caused by the lack of confidence in public preferences and sociopolitical structures as well as the uncertainty regarding scientific evidence related to physical processes. To solve this, they suggested that both sociopolitical and biophysical uncertainties must be identified and managed within the framework for designing and delivering sustainable urban flood risk management.

Schifman et al. (2017) proposed a framework for adaptive socio-hydrology (FrASH) that can be used in NBS planning and implementation by bringing ideas together from socio-hydrology; the capacity for adaptation, participation and inclusiveness; and organised action. The framework also helps in creating a connected network between municipalities, public-works departments, organisations and people in the community. This potentially allows for the management of resilience in the system at multiple scales.

Often, it is not as easy to address socio-economic issues as technical questions. These socio-economic issues include perception and acceptance, policies, interdisciplinary nature, education, and documenting the economic benefit of NBS implementation (Alves et al., 2018a; Santoro et al., 2019; Vogel et al., 2015). Nevertheless, social-science research (i.e. surveys, interviews and focus groups) helps to review and gain insights into the obstacles and motivations for implementing NBSs as well as to understand a community's resilience and stakeholders' risk perception (Matthews et al., 2015; Santoro et al., 2019), for instance, bringing the findings to stakeholders and community members to discuss what level of flood hazards is acceptable and what level of climate change adaptation capacity the community plans to achieve (Brown et al., 2012). Moreover, sociopolitical dynamics in NBSs is still lacking; there are few case studies available that critically evaluate the politics of NBSs in the role of community mobilisation (Triyanti and Chu, 2018). Not only it is essential to involve stakeholders in the selection, planning, design and implementation of NBSs, but it is 
also important for bridging gaps between researchers, engineers, politicians, managers and stakeholders. This may help to improve our capacity for using both small- and large-scale NBSs. There are good documentations of policy arrangements, scientific niches and the current status of governance studies of NBSs that were reviewed by Scarano (2017) and Triyanti and Chu (2018).

\subsection{Multiple benefits of NBSs}

The literature on a NBS and its sister concepts increasingly refers to multiple benefits of social, economic and environmental enhancements. The reason for this is that NBSs are regarded as sustainable solutions that use ecosystem services to provide multiple benefits for human well-being and the environment, which differs from grey infrastructure. Moreover, these multiple benefits of NBSs can help to achieve many of the goals of the 2030 Agenda for Sustainable Development. The recent publication shows how NBSs can contribute to achieving the SDGs (Seifollahi-Aghmiuni et al., 2019). This publication reports that wetland ecosystem services in Sweden positively interact with SDG 1 (no poverty), SDG 2 (zero hunger), SDG 3 (good health and well-being), SDG 6 (clean water and sanitation), SDG 7 (affordable and clean energy), SDG 11 (sustainable cities and communities), SDG 12 (responsible consumption and production), SDG 13 (climate action), SDG 14 (life below water) and SDG 15 (life on land). One of the processes that could provide these benefits is to give more significant consideration to landscape function, adaptive and multi-functionality design (Lennon et al., 2014; Vojinovic et al., 2017), restoring naturally occurring ecosystems, and promoting desirable soil (Keesstra et al., 2018).

The literature to date shows that multiple challenges can be continually addressed through NBSs. These include reducing flood risk (Song et al., 2018), storing and infiltrating rainfall run-off, delaying and reducing surface run-off, reducing erosion and particulate transport (Loperfido et al., 2014), recharging groundwater discharge, reducing pollution from surface water (Donnell et al., 2018), increasing nutrient retention and removal (Loperfido et al., 2014), maintaining soil moisture, and enhancing vegetation growth. Such benefits help in reaching SDG 6 - ensuring sustainable water management.

Beyond water management, the case for NBSs includes their ability to provide additional benefits in improving socio-economic aspects (SDG 11) and human well-being (SDG 3) through recreational areas and aesthetic value (Song et al., 2018) as well as encouraging tourism through the access to nature (Sutton-Grier et al., 2018). Wheeler et al. (2010) quantified the volume and intensity of children's physical activity in green space and found that time in green space is more likely to lead to greater activity intensity amongst children. The use of NBSs can bring economic benefits (SDG 1 and SDG 8) in different ways, such as re- duced or prevented damage costs from hydro-meteorological events, energy savings from the reduction of stormwater that typically needs to be treated in a public sewerage system, and carbon savings from reduced building energy consumption (heating and cooling; Soares et al., 2011). Such energy and carbon savings will help contribute to SDG 13.

The environmental benefits of NBS measures can have various positive impacts. Some of the most important are the ability to enhance environmental and ecosystem services by connecting habitat and biodiversity (Hoang et al., 2018; Reguero et al., 2018; Thorslund et al., 2017), increasing carbon consequences, reducing air and noise pollution (Donnell et al., 2018), and improving urban heat island effect mitigation (Majidi et al., 2019; Raymond et al., 2017). Zhang and Chui (2019) reviewed the hydrological and bio-ecological benefits of NBSs across spatial scales and suggested that there should be more research at the catchment scale to consider the full benefits of NBSs.

The hydrological and water quality benefits of NBSs have been widely reviewed and discussed, but there are few articles that focus on evaluating the multiple benefits of NBSs. Doing so could help raise awareness and enhance the institutional and social acceptance of these measures (Pagano et al., 2019). Hoang et al. (2018) proposed a new integrated methodology using a GIS approach to assess benefits and disadvantages of NBSs, which include habitat connectivity, recreational accessibility, traffic movement, noise propagation, carbon sequestration, pollutant trapping and water quality. Donnell et al. (2018) used BeST and the Blue-Green Cities toolbox to assess benefits, and Mills et al. (2016) assessed air pollution reduction based on tree canopy cover. Alves et al. (2019) presented a novel methodology for valuing co-benefits for NBS applications in urban contexts. Fenner (2017) recommended that their spatial distribution should be assessed through multi-functional design, making it possible to identify how this is valuable to stakeholders and where the overall aggregated benefits occur. However, there is still a need for deeper understanding of assessment of the multiple benefits of NBSs (Liu et al., 2017). A challenge is the lack of information on the values of ecosystem and multi-related ecosystem economic valuation.

\subsection{Trends, knowledge gaps and future research prospects}

The literature material reviewed in this study showed that NBSs have not been equally applied to all hydrometeorological risk reduction contexts. The review identified, in total, 1204 journal articles from 2007 to the end of 2019. The analysis of publications from 2007 to 2019 shows that only 121 out of 1439 articles (i.e. $11 \%$ ) explicitly used the term nature-based solution for hydrometeorological risk reduction (Fig. 5). This can be explained due to the term NBSs being used only after 2008 (MacKinnon et al., 2008), while other terms were used earlier in 


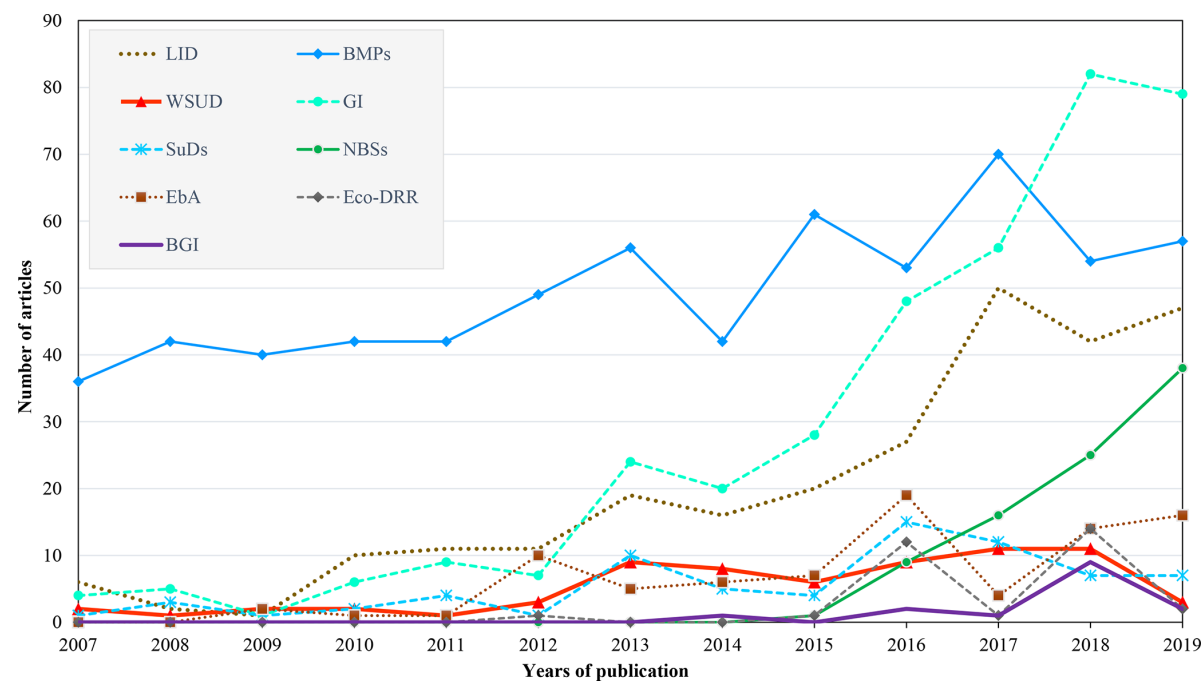

Figure 5. Number and trend of published articles on nature-based solutions (NBSs) for hydro-meteorological risk reduction and their sister terms: low-impact developments (LIDs), best management practices (BMPs), water-sensitive urban design (WSUD), green infrastructure (GI), sustainable urban drainage systems (SuDs), nature-based solutions (NBSs), ecosystem-based adaptation (EbA), ecosystem-based disaster risk reduction (Eco-DRR) and blue-green infrastructure (BGI).

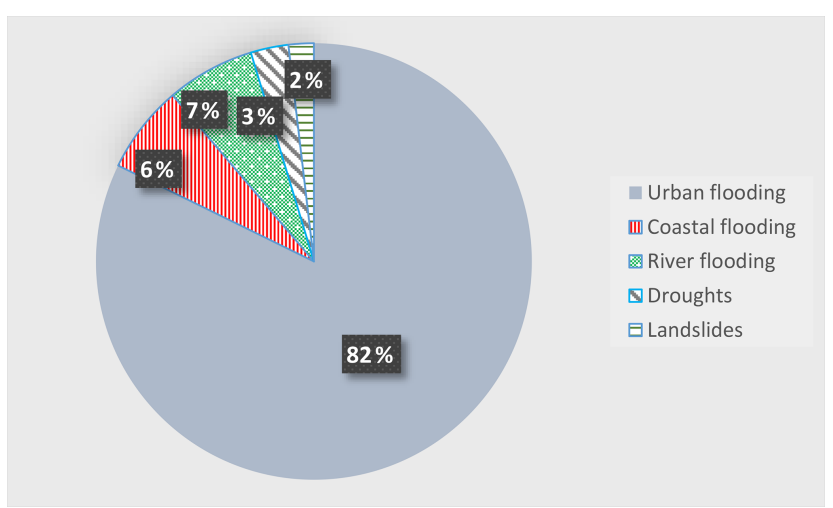

Figure 6. Percentage of published articles that have been studied on nature-based solutions (NBSs) for different types of hydrometeorological risks.

different countries (Fig. 1). However, the significant increase in published articles in recent years shows how NBSs are a rapidly growing research area (Fig. 5).

One hundred forty-six publications of NBSs for hydrometeorological risk reduction were reviewed. Most of the literature to date is about NBSs in urban areas, whereas the contexts concerning river and coastal floods, droughts, and landslides are the least addressed; $82 \%$ of all articles were concerned with run-off reduction or flood risk reduction in urban areas (Fig. 6). Even when there were 2 search terms that include "Urban" out of the 10 search terms, it contributed to only $2.7 \%$ of the total $82 \%$ urban cases. The large-scale NBSs is only 16 articles, mostly focusing on river and coastal flooding (Table 5).
An overview of quantitative results, some research gaps and future research prospects is given in Table 6. This table indicates subjects or areas in which knowledge is missing or insufficient. The knowledge gaps have been divided into eight subjects, which are the effectiveness of small-scale NBSs, the effectiveness of large-scale NBSs, selection and assessment of NBSs with focus on risk reduction, multiple benefits of NBSs, application of tools, multi-functional design, stakeholder participation, and financial governance and policy. Some of the key challenges' concluding remarks are summarised below.

There is a clear gap between the amount of research on small-scale NBSs in urban areas and large-scale NBSs at the catchment (river basin), rural and regional scale. The reason for this is that a large-scale system is more complex than a small system. Therefore, research and frameworks that deal with the problem of reducing hydro-meteorological risk with upscaling NBSs from the urban scale to the catchment (river basin) scale would be beneficial, and it would also be beneficial to understand both the natural processes of large-scale NBSs and how they change over time. Furthermore, there are only a few studies that combine NBSs at both the small and large scale, and further research in this direction is highly desirable.

Obviously, there is no single NBS that can solve all problems. Every project needs to be designed to address a particular challenge in its local contexts and in its respective community. Therefore, an understanding of site conditions is necessary for NBSs to achieve the target of the project.

Based on the findings of the literature review, there are still challenges in relation to methods and tools for planning and implementing NBSs. These include improving and develop- 
Table 5. Overview of knowledge gaps and potential future research prospects.

\begin{tabular}{|c|c|c|c|}
\hline Subject & $\begin{array}{l}\text { Number of } \\
\text { publications }\end{array}$ & Knowledge gaps & Future research prospects \\
\hline $\begin{array}{l}\text { 1. The } \\
\text { effectiveness } \\
\text { of small-scale } \\
\text { NBSs }\end{array}$ & 41 & $\begin{array}{l}\text { - Combination of small- and } \\
\text { large-scale NBSs with grey } \\
\text { infrastructure } \\
\text { - NBSs for droughts, } \\
\text { landslides and storm surges }\end{array}$ & $\begin{array}{l}\text { - Development of a framework and methods to upscale NBSs from small to } \\
\text { large scale } \\
\text { - Development of a framework, methods and tools to select, evaluate and } \\
\text { design hybrid measures for hydro-meteorological risk reduction } \\
\text { - Application of NBSs to reduce the risk of droughts, landslides and storm } \\
\text { surges }\end{array}$ \\
\hline $\begin{array}{l}\text { 2. The } \\
\text { effectiveness of } \\
\text { large-scale NBSs }\end{array}$ & 10 & $\begin{array}{l}\text { - Application to hydro- } \\
\text { meteorological risk } \\
\text { reduction } \\
\text { - Combination of large-scale } \\
\text { NBSs with grey measures }\end{array}$ & $\begin{array}{l}\text { - Development of a framework, methods and tools to select, evaluate and } \\
\text { design large-scale NBSs individually and in hybrid combinations for hydro- } \\
\text { meteorological risk reduction } \\
\text { - Development of typologies and guidelines for NBS design, } \\
\text { implementation, operation and maintenance }\end{array}$ \\
\hline \multirow[t]{4}{*}{$\begin{array}{l}\text { 3. Selection and } \\
\text { assessment of } \\
\text { NBSs with the } \\
\text { focus on risk } \\
\text { reduction }\end{array}$} & \multirow[t]{4}{*}{27} & $\begin{array}{l}\text { Framework for selection of } \\
\text { NBSs }\end{array}$ & $\begin{array}{l}\text { - Defining the role of ecosystems in terms of risk reduction, socio- } \\
\text { economic and hydro-geomorphological settings } \\
\text { - Combining spatial planning and stakeholder participation in the } \\
\text { co-selection process }\end{array}$ \\
\hline & & Framework for cost analysis & $\begin{array}{l}\text { - Combining economic value of ecological damage and environmental } \\
\text { impact, including the "invisible" ecosystem services (see also Estrella } \\
\text { et al., 2013) } \\
\text { - Application of the whole life cycle costing and return on investment } \\
\text { within the cost-benefit analysis of NBSs } \\
\text { - Comparing costs and benefits between NBSs, GI and hybrid measures } \\
\text { - Defining opportunity costs and trade-offs of NBS implementation }\end{array}$ \\
\hline & & $\begin{array}{l}\text { Framework for optimal } \\
\text { configuration of NBSs }\end{array}$ & $\begin{array}{l}\text { - Use of optimisation techniques to maximise the main benefit and co- } \\
\text { benefits of NBSs while minimising their costs } \\
\text { - Use of optimisation techniques to maximise the efficiency of NBSs and to } \\
\text { define their best configurations within hybrid solutions } \\
\text { - Assessing the effectiveness of solutions in short and long term }\end{array}$ \\
\hline & & $\begin{array}{l}\text { Combination between } \\
\text { multi-criteria and qualitative } \\
\text { research }\end{array}$ & $\begin{array}{l}\text { - Use of multi-criteria and qualitative research in evaluation of NBSs } \\
\text { - How to combine quantitative and qualitative data and research methods } \\
\text { - Application of qualitative research methods and interviews to } \\
\text { effectiveness of NBSs }\end{array}$ \\
\hline \multirow[t]{2}{*}{$\begin{array}{l}\text { 4. Multiple } \\
\text { benefits of NBSs }\end{array}$} & \multirow[t]{2}{*}{23} & $\begin{array}{l}\text { Assessment of multiple } \\
\text { benefits of NBSs }\end{array}$ & $\begin{array}{l}\text { - Quantification of co-benefits } \\
\text { - Development of a framework, methods and tools to evaluate wide-ranging } \\
\text { intangible and tangible benefits } \\
\text { - Gaining deeper understanding of NBS benefits for human well-being }\end{array}$ \\
\hline & & $\begin{array}{l}\text { Assessment of ecosystem } \\
\text { capacity }\end{array}$ & $\begin{array}{l}\text { - Assessing ecosystem capacity to maintain services over a longer period of } \\
\text { time (see Estrella and Saalismaa, 2013) } \\
\text { - Long-term monitoring and evaluation of ecosystem performance and } \\
\text { function before and after the disaster } \\
\text { - Addressing the complexity of coupled social and ecological systems }\end{array}$ \\
\hline \multirow[t]{2}{*}{$\begin{array}{l}\text { 5. Application } \\
\text { of tools }\end{array}$} & \multirow[t]{2}{*}{18} & $\begin{array}{l}\text { Application of new } \\
\text { technologies and concepts } \\
\text { (e.g. high-resolution } \\
\text { numerical models, complex, } \\
\text { crowdsourcing tools, real- } \\
\text { time control system) }\end{array}$ & $\begin{array}{l}\text { - Integration of real-time monitoring and control technologies for NBSs } \\
\text { operation } \\
\text { - A trade-off between high-resolution numerical models and accuracy of } \\
\text { results } \\
\text { - Use of novel modelling techniques such as complex adaptive systems } \\
\text { models and serious games }\end{array}$ \\
\hline & & $\begin{array}{l}\text { Web-based decision support } \\
\text { tools and systems }\end{array}$ & $\begin{array}{l}\text { - Development of databases of small- and large-scale NBSs for hydro- } \\
\text { meteorological risk reduction } \\
\text { - Development of platforms, info systems and clusters for exchange of } \\
\text { knowledge (see also Kabisch et al., 2016) } \\
\text { - Development of tools to support decision makers in selecting and } \\
\text { evaluating hybrid measures } \\
\text { - Development of tools to assess the multiple benefits for small and large } \\
\text { scale NBSs and their hybrid combinations }\end{array}$ \\
\hline
\end{tabular}


Table 5. Continued.

\begin{tabular}{|c|c|c|c|}
\hline Subject & $\begin{array}{l}\text { Number of } \\
\text { publications }\end{array}$ & Knowledge gaps & Future research prospects \\
\hline $\begin{array}{l}\text { 6. Multi-functional } \\
\text { design }\end{array}$ & 2 & $\begin{array}{l}\text { Framework for } \\
\text { multi-functional design }\end{array}$ & $\begin{array}{l}\text { - Development of a framework and methods to support multi-functional } \\
\text { design } \\
\text { - Application of novel landscape design techniques } \\
\text { - Combining the knowledge from landscape architecture and water } \\
\text { engineering (Kabisch et al., 2016) }\end{array}$ \\
\hline $\begin{array}{l}\text { 7. Stakeholder } \\
\text { participation }\end{array}$ & 9 & $\begin{array}{l}\text { Frameworks for effective } \\
\text { stakeholder involvement } \\
\text { and co-creation }\end{array}$ & $\begin{array}{l}\text { - Frameworks for involvement of stakeholders in the selection, evaluation, } \\
\text { design, implementation and monitoring of NBSs (i.e. the so-called co- } \\
\text { creation process) }\end{array}$ \\
\hline \multirow[t]{3}{*}{$\begin{array}{l}\text { 8. Financing, } \\
\text { governance } \\
\text { and policy }\end{array}$} & \multirow[t]{3}{*}{4} & $\begin{array}{l}\text { Desirable governance } \\
\text { structures to support } \\
\text { effective implementation } \\
\text { and operation of NBSs at } \\
\text { different scales and contexts }\end{array}$ & $\begin{array}{l}\text { - Information concerning legal instruments and requirements } \\
\text { - Development of effective governance structures } \\
\text { - Compilation of data and information concerning multiple actors and } \\
\text { institutions which are relevant for implementation of NBSs } \\
\text { - Understanding water governance structures, drivers, barriers and } \\
\text { mechanisms for enabling system transformation (see also Albert et al., } \\
\text { 2019) } \\
\text { - Development of methods for evaluation of social, political and } \\
\text { institutional dimensions of NBSs (see also Triyanti and Chu, 2018) }\end{array}$ \\
\hline & & $\begin{array}{l}\text { Desirable financial models } \\
\text { (e.g. public-private } \\
\text { partnerships, blended } \\
\text { financing, etc.) }\end{array}$ & $\begin{array}{l}\text { - Development of financial guidance for implementing maintaining and } \\
\text { operating NBS projects } \\
\text { - Guidelines concerning development of new business and financial models } \\
\text { (see also Kabisch et al., 2016) } \\
\text { - Development of financial mechanisms to engage public and private } \\
\text { sectors in the implementation of NBSs }\end{array}$ \\
\hline & & $\begin{array}{l}\text { Bridging gaps between } \\
\text { science, practice and policy }\end{array}$ & $\begin{array}{l}\text { - Bridging gaps between researchers, engineers, authorities and local } \\
\text { stakeholders } \\
\text { - Bridging the policy and institutional gaps } \\
\text { - Bringing innovation to engage society in implementing and improving } \\
\text { NBSs }\end{array}$ \\
\hline
\end{tabular}

ing methods for assessing co-benefits (especially social and ecological benefits, i.e. aesthetical values, community liveability and human health), frameworks and methods for evaluating large-scale NBSs, and hybrid measures (i.e. combinations of grey infrastructure and small- and large-scale NBSs).

There are also challenges in incorporating local stakeholder participation within the framework and models and within the assessment and implementation process. Other challenges regarding governance are to develop guidance on effective models of governance and provide information on actors, institutions and legal instruments, and other requirements that are relevant for implementing NBSs. The reason for this is the lack of workable frameworks that can bring together a variety of stakeholder groups. Moreover, there is still a lack of financial studies and guidelines for cost-effective implementation, maintenance and operation of NBS projects, and mechanisms that can be used to promote new business and financial models for successful implementation of NBSs.

There should also be more efforts in the development of assessment tools that incorporate new technologies such as real-time control systems, forecast models and coupled models to provide more active and integrated operational solutions (i.e. SMART NBSs). There is a need for the develop- ment of databases that include functions, benefits and costs of large and small-scale NBSs to facilitate future research.

\section{Conclusions}

The present paper provides a critical review of the literature and identifies future research prospects based on the current knowledge gaps in the area of nature-based solutions for hydro-meteorological risk reduction by using a systematic review. The systematic review method helps to limit the scope of the work and also provides useful direction for defining research gaps, as articles can be collected from a board range of sources. However, there are some disadvantages of systematic reviews. For example, a finite selection of keywords will introduce gaps into the list of articles to be reviewed. Also, important grey literature (e.g. reports and books) could be overlooked. Finally, poorly written abstracts may cause an article to be excluded from the review.

The review process started by analysing 1608 articles sourced from Scopus and 1431 articles from the Web of Science from 1 January 2007 to 19 November 2019. The final full analysis was performed on 146 articles. The systematic 
Table 6. An overview of web portals, networks and initiatives that address nature-based solutions.

\begin{tabular}{|c|c|c|c|c|c|}
\hline Name & $\begin{array}{l}\text { References and } \\
\text { website }\end{array}$ & $\begin{array}{l}\text { Terminology } \\
\text { used }\end{array}$ & $\begin{array}{l}\text { Scale } \\
\text { level }\end{array}$ & Funder & Proposes \\
\hline OPPLA & Oppla (2019) & $\begin{array}{l}\text { Nature-based } \\
\text { solution, natural } \\
\text { capital, } \\
\text { ecosystem } \\
\text { services }\end{array}$ & Europe & FP7 (EC) & $\begin{array}{l}\text { A new knowledge marketplace - EU } \\
\text { repository of NBSs - a place where the latest } \\
\text { thinking on ecosystem services, natural } \\
\text { capital and nature-based solutions is } \\
\text { brought together. }\end{array}$ \\
\hline BiodivERsA & $\begin{array}{l}\text { Biodivera } \\
(2019)\end{array}$ & $\begin{array}{l}\text { Ecosystem } \\
\text { services }\end{array}$ & Europe & $\begin{array}{l}\text { Horizon } \\
2020(\mathrm{EC})\end{array}$ & $\begin{array}{l}\text { A network of funding organisations } \\
\text { promoting research on biodiversity and } \\
\text { ecosystem services. }\end{array}$ \\
\hline BISE & BISE (2019) & $\begin{array}{l}\text { Ecosystem } \\
\text { services, green } \\
\text { infrastructures }\end{array}$ & Europe & $\mathrm{EC}$ & $\begin{array}{l}\text { A single entry point for data and } \\
\text { information on biodiversity supporting the } \\
\text { implementation of the EU strategy and the } \\
\text { Aichi Targets in Europe. }\end{array}$ \\
\hline ThinkNature & $\begin{array}{l}\text { ThinkNature } \\
\text { (2019) }\end{array}$ & $\begin{array}{l}\text { Nature-based } \\
\text { solution }\end{array}$ & Europe & $\begin{array}{l}\text { Horizon } \\
2020 \text { (EC) }\end{array}$ & $\begin{array}{l}\text { A multi-stakeholder communication } \\
\text { platform that supports dialogue and } \\
\text { understanding of NBSs. }\end{array}$ \\
\hline Climate-ADAPT & $\begin{array}{l}\text { Climate } \\
\text { ADAPT (2019) }\end{array}$ & $\begin{array}{l}\text { Ecosystem-based adaptation, } \\
\text { nature-based solution, } \\
\text { green infrastructures }\end{array}$ & Europe & EC, EEA & $\begin{array}{l}\text { A platform that supports Europe in } \\
\text { adapting to climate change by helping users } \\
\text { to access and share data and information } \\
\text { relevant for CCIVA. }\end{array}$ \\
\hline $\begin{array}{l}\text { Natural Water } \\
\text { Retention } \\
\text { Measures }\end{array}$ & NWRM (2019) & $\begin{array}{l}\text { Natural water } \\
\text { retention } \\
\text { measures }\end{array}$ & Europe & $\mathrm{EC}$ & $\begin{array}{l}\text { A platform that gathers information on } \\
\text { NWRM at EU level. }\end{array}$ \\
\hline $\begin{array}{l}\text { Urban Nature } \\
\text { Atlas }\end{array}$ & $\begin{array}{l}\text { NATURVATION } \\
\text { (2019) }\end{array}$ & $\begin{array}{l}\text { Nature-based } \\
\text { solution }\end{array}$ & Europe & $\begin{array}{l}\text { Horizon } \\
2020 \text { (EC) }\end{array}$ & $\begin{array}{l}\text { A platform that contains around } 1000 \\
\text { examples of nature-based solutions from } \\
\text { across } 100 \text { European cities. }\end{array}$ \\
\hline $\begin{array}{l}\text { Disaster Risk } \\
\text { Management } \\
\text { Knowledge } \\
\text { Centre }\end{array}$ & DRMKC (2019) & Eco-DRR & Europe & $\mathrm{EC}$ & $\begin{array}{l}\text { A platform that provides a networked } \\
\text { approach to the science-policy interface in } \\
\text { DRM. }\end{array}$ \\
\hline $\begin{array}{l}\text { Natural } \\
\text { Hazards - } \\
\text { Nature-based } \\
\text { Solutions }\end{array}$ & $\begin{array}{l}\text { World Bank et } \\
\text { al. (2019) }\end{array}$ & $\begin{array}{l}\text { Nature-based } \\
\text { solution }\end{array}$ & Global & $\begin{array}{l}\text { The World } \\
\text { Bank }\end{array}$ & $\begin{array}{l}\text { A project map that provides a list of nature- } \\
\text { based projects that are sortable by } \\
\text { implementing organisation; targeted } \\
\text { hazard; and type of nature-based solution, } \\
\text { geographic location, cost, benefits and } \\
\text { more. }\end{array}$ \\
\hline $\begin{array}{l}\text { Nature-based } \\
\text { Solutions } \\
\text { Initiative }\end{array}$ & $\begin{array}{l}\text { Nature-based } \\
\text { Solutions } \\
\text { Initiative } \\
(2019)\end{array}$ & $\begin{array}{l}\text { Nature-based } \\
\text { solution }\end{array}$ & Global & $\begin{array}{l}\text { International } \\
\text { Institute for } \\
\text { Environment } \\
\text { and } \\
\text { Development } \\
\text { (IIED) }\end{array}$ & $\begin{array}{l}\text { The global policy platform that provides } \\
\text { information about climate change } \\
\text { adaptation planning across the globe } \\
\text { that is openly available and easy to explore. }\end{array}$ \\
\hline weADAPT & SEI (2019) & $\begin{array}{l}\text { Ecosystem- } \\
\text { based adaptation }\end{array}$ & Global & $\begin{array}{l}\text { Stockholm } \\
\text { Environment } \\
\text { Institute } \\
\text { (SEI) }\end{array}$ & $\begin{array}{l}\text { A collaborative platform on climate } \\
\text { adaptation issues, which allows } \\
\text { practitioners, researchers and policymakers } \\
\text { to access credible, high-quality } \\
\text { information and connect. }\end{array}$ \\
\hline Nature of Cities & $\begin{array}{l}\text { Nature of } \\
\text { Cities (2019) }\end{array}$ & $\begin{array}{l}\text { Green } \\
\text { infrastructures }\end{array}$ & Global & & $\begin{array}{l}\text { An international platform for } \\
\text { transdisciplinary dialogue concerning } \\
\text { urban solutions. }\end{array}$ \\
\hline
\end{tabular}


Table 6. Continued.

\begin{tabular}{|c|c|c|c|c|c|}
\hline Name & $\begin{array}{l}\text { References and } \\
\text { website }\end{array}$ & $\begin{array}{l}\text { Terminology } \\
\text { used }\end{array}$ & $\begin{array}{l}\text { Scale } \\
\text { level }\end{array}$ & Funder & Proposes \\
\hline ClimateScan & $\begin{array}{l}\text { ClimateScan } \\
(2019)\end{array}$ & $\begin{array}{l}\text { Blue-green } \\
\text { infrastructures }\end{array}$ & Global & $\mathrm{EC}$ & $\begin{array}{l}\text { Global online tool which acts as a guide for } \\
\text { projects and initiatives on urban resilience, } \\
\text { climate proofing and climate adaptation } \\
\text { around the world. }\end{array}$ \\
\hline $\begin{array}{l}\text { Partnership for } \\
\text { Environment } \\
\text { and Disaster } \\
\text { Risk Reduction } \\
\text { (PEDRR) }\end{array}$ & PEDRR (2019) & $\begin{array}{l}\text { Ecosystem- } \\
\text { based adaptation }\end{array}$ & Global & & $\begin{array}{l}\text { PEDRR aims to promote and upscale } \\
\text { implementation of Eco-DRR and ensure it } \\
\text { is mainstreamed in development planning } \\
\text { at global, national and local levels, in line } \\
\text { with the SFDRR. }\end{array}$ \\
\hline PANORAMA & $\begin{array}{l}\text { PANORAMA } \\
(2019)\end{array}$ & $\begin{array}{l}\text { Ecosystem- } \\
\text { based adaptation }\end{array}$ & Global & $\begin{array}{l}\text { IUCN, } \\
\text { GIZ, } \\
\text { UNDP }\end{array}$ & $\begin{array}{l}\text { It aims to document and promote examples } \\
\text { of inspiring solutions across development } \\
\text { topics and to enable cross-sectoral learning and } \\
\text { upscaling of successes }\end{array}$ \\
\hline
\end{tabular}

review has shown that considerable achievements have been made to date. However, there are still many challenges and opportunities that will play an important role in extending the knowledge of NBSs in the coming years. Some examples of research gaps are combining small-scale and largescale NBSs; the effectiveness of NBSs in reducing risk at the regional and catchment scale; the frameworks, methods and tools for assessing co-benefits; involvement of local stakeholders in the selection; assessment and implementation process; integration of NBSs with new technologies; and development of NBS databases.

The effectiveness, benefits and acceptance of NBSs are dependent on the implementation purpose, local context and cultural setting. For example, small-scale NBSs (e.g. swales, green roofs or porous pavements) are more suitable for urban flooding, while large-scale NBSs (river restoration, dunes or wetlands) are more suitable for river floods, coastal floods, droughts and landslides. Small-scale NBSs are more effective in reducing flood peaks for smaller-magnitude frequent storms (e.g. 2-year return period) than larger-magnitude infrequent storms (e.g. 10-year return period). Large-scale NBSs can provide more benefits compared to small-scale NBSs because they encompass larger spaces; thus more functions can be included in the design process. For example, the Laojie River project in Taoyuan in Taiwan changed the channel into an accessible green corridor. This project helps in reducing flood risk, improving riverside landscapes, increasing recreation area, increasing the aesthetic value and improving river water quality. On the other hand, small-scale NBSs need less area because most of the measures can be implemented in the free space. For example, green roofs can be implemented on the roofs of buildings, and permeable pavements can be implemented in car parks. Investments in NBSs will benefit society by providing cost-effective measures and adaptive strategies that protect communities and achieve a range of co-benefits. Moreover, bridging the gaps between researchers, engineers and stakeholders will help to improve the capacity of NBSs in reducing hydro-meteorological risk as well as increasing their benefits. Strengthening these aspects may be beneficial for improving acceptance of NBSs at the local level.

Horizon 2020 projects, namely RECONECT, PHUSICOS and OPERANDUM, were initiated in 2018 to help bridge the gaps in the innovation of NBSs and to test their efficacy in rural, mountain and transition land environments. Development of techniques, methods and tools for planning, selecting, evaluating and implementing NBSs are among the common products of RECONECT, PHUSICOS and OPERANDUM. 


\section{Appendix A: Abbreviations}

\begin{tabular}{|c|c|}
\hline AST & Adaptation Support Tool \\
\hline BeST & Benefits of SuDs Tool \\
\hline BGI & Blue-green infrastructure \\
\hline BMPDSS & Best management practice decision support \\
\hline BMPs & Best management practices \\
\hline CBA & Cost-benefit analyses \\
\hline CBD & Convention on Biological Diversity \\
\hline $\mathrm{CCA}$ & Climate change adaptation \\
\hline CEM & Commission on Ecosystem Management \\
\hline DRR & Disaster risk reduction \\
\hline $\mathrm{EbA}$ & Ecosystem-based adaptation \\
\hline Eco-DRR & Ecosystem-based disaster risk reduction \\
\hline $\mathrm{EC}$ & European Commission \\
\hline FrASH & Framework for adaptive socio-hydrology \\
\hline GI & Green infrastructure \\
\hline IIED & International Institute for Environment and Development \\
\hline IUCN & International Union for Conservation of Nature \\
\hline LCC & Life cycle costing \\
\hline LID & Low impact development \\
\hline L-THIA-LID & Long-Term Hydrologic Impact Assessment-Low Impact Development \\
\hline MAUT & Multi-attribute utility theory \\
\hline MCA & Multi-criteria analysis \\
\hline MLSOP & Multilevel spatial optimisation \\
\hline MOEAs & Most popular multiobjective evolutionary algorithms \\
\hline MOO & Multi-objective optimal \\
\hline MOPSO & Multi-objective particle swarm optimisation \\
\hline MUSIC & Model for Urban Stormwater Improvement Conceptualization \\
\hline NBSs & Nature-based solutions \\
\hline NSGA-II & Non-dominated sorting genetic algorithm II \\
\hline PSO & Particle swarm optimisation \\
\hline RECONECT & Regenerating ECOsystems with Nature-based solutions for hydro-meteorological risk rEduCTion \\
\hline ROI & Return on investment \\
\hline RPE & Relative performance evaluation \\
\hline SA & Simulated annealing \\
\hline SCADA & Supervisory control and data acquisition \\
\hline $\mathrm{SCP}$ & Sponge City Programme \\
\hline SDGs & Sustainable Development Goals \\
\hline SEI & Stockholm Environment Institute \\
\hline SFDRR & Sendai Framework for Disaster Risk Reduction \\
\hline SUDCLOC & SuD selection and location \\
\hline SuDs & Sustainable urban drainage systems \\
\hline SUSTAIN & System for Urban Stormwater Treatment and Analysis IntegratioN \\
\hline SWAT & Soil and water assessment \\
\hline SWMM & Storm Water Management Model \\
\hline TSS & Total suspended solids \\
\hline UN & United Nations \\
\hline UNFCCC & UN Framework Convention on Climate Change \\
\hline US EPA & United States Environmental Protection Agency \\
\hline UrbanBEATS & The Urban Biophysical Environments and Technologies Simulator \\
\hline UWOT & Urban water optioneering tool \\
\hline WSUD & Water-sensitive urban design \\
\hline
\end{tabular}


Data availability. Data are available upon request to the corresponding author.

Author contributions. LR and ZV designed the objectives of the review. LR selected, read and analysed the articles. LR, ZV, SDS and LSL were involved in the production of the paper. LL and ZV produced the figures. The other authors contributed to the paper with comments and suggestions. All authors contributed to the writing, editing and revision of the paper.

Competing interests. The authors declare that they have no conflict of interest.

Acknowledgements. Production of this article received funding from the European Union's Horizon 2020 Research and Innovation programme under grant agreement no. 776866 for the research project RECONECT (Regenerating ECOsystems with Naturebased solutions for hydro-meteorological risk rEduCTion). It was also supported by the European Union's Horizon 2020 Research and Innovation programme under grant agreement no. 776848 for OPERANDUM and under grant agreement no. 776681 for PHUSICOS. The study reflects only the authors' view, and the European Union is not liable for any use that may be made of the information contained herein.

Financial support. This research has been supported by the Horizon 2020 programme (grant nos. 776866, 776848 and 776681).

Review statement. This paper was edited by Margreth Keiler and reviewed by Karen Sudmeier-Rieux and two anonymous referees.

\section{References}

Ahiablame, L. M., Engel, B., and Chaubey, I.: Representation and Evaluation of Low Impact Development Practices with L-THIALID: An Example for Site Planning, Environ. Pollut., 1, 1-13, https://doi.org/10.5539/ep.v1n2p1, 2012.

Albert, C., Schröter, B., Haase, D., Brillinger, M., Henze, J., Herrmann, S., Gottwald, S., Guerrero, P., Nicolas, C., and Matzdorf, B.: Addressing societal challenges through naturebased solutions: How can landscape planning and governance research contribute?, Landsc. Urban Plan., 182, 12-21, https://doi.org/10.1016/j.landurbplan.2018.10.003, 2019.

Alves, A., Sanchez, A., Vojinovic, Z., Seyoum, S., Babel, M., and Brdjanovic, D.: Evolutionary and holistic assessment of green-grey infrastructure for CSO reduction, Water, 8, 402, https://doi.org/10.3390/w8090402, 2016.

Alves, A., Gómez, J. P., Vojinovic, Z., Sánchez, A., and Weesakul, S.: Combining Co-Benefits and Stakeholders Perceptions into Green Infrastructure Selection for Flood Risk Reduction, Environments, 5, 29, https://doi.org/10.3390/environments5020029, 2018a.
Alves, A., Gersonius, B., Sanchez, A., Vojinovic, Z., and Kapelan, Z.: Multi-criteria Approach for Selection of Green and Grey Infrastructure to Reduce Flood Risk and Increase CO-benefits, Water Resour. Manage., 32, 2505-2522, https://doi.org/10.1007/s11269-018-1943-3, 2018b.

Alves, A., Gersonius, B., Kapelan, Z., Vojinovic, Z., and Sanchez, A.: Assessing the Co-Benefits of greenblue-grey infrastructure for sustainable urban flood risk management, J. Environ. Manage., 239, 244-254, https://doi.org/10.1016/j.jenvman.2019.03.036, 2019.

atelier GROENBLAUW: Green-blue design tool, available at: https://www.urbangreenbluegrids.com/design-tool/, last access: 1 February 2019.

Behroozi, A., Niksokhan, M. H., and Nazariha, M.: Developing a simulation-optimisation model for quantitative and qualitative control of urban run-off using best management practices, J. Flood Risk Manage., 11, S340-S351, https://doi.org/10.1111/jfr3.12210, 2018.

Bhattacharjee, K. and Behera, B.: Does forest cover help prevent flood damage? Empirical evidence from India, Global Environ. Change, 53, 78-89, https://doi.org/10.1016/j.gloenvcha.2018.09.004, 2018.

Biodivera: BiodivERsA, available at: https://www.biodiversa.org/, last access: 5 March 2019.

BISE: BISE - Biodiversity Information System for Europe - Biodiversity Information system for Europe, available at: https:// biodiversity.europa.eu/, last access: 5 March 2019.

Bosch Slabbers, Deltares, Swexo, Witteveen+Bos, and KNMI: Climate Adaptive Solutions, available at: http://www.climateapp. nl/, last access: 1 February 2019.

Brown, C., Ghile, Y., Laverty, M., and Li, K.: Decision scaling: Linking bottom-up vulnerability analysis with climate projections in the water sector, Water Resour. Res., 48, 1-12, https://doi.org/10.1029/2011WR011212, 2012.

Burszta-Adamiak, E. and Mrowiec, M.: Modelling of Green roofs' hydrologic performance using EPA's SWMM, Water Sci. Technol., 68, 36-42, https://doi.org/10.2166/wst.2013.219, 2013.

Carpenter, D. D. and Kaluvakolanu, P.: Effect of Roof Surface Type on Storm-Water Runoff from Full-Scale Roofs in a Temperate Climate, J. Irrig. Drain. Eng., 137, 161-169, https://doi.org/10.1061/(ASCE)IR.1943-4774.0000185, 2011.

Casteller, A., Häfelfinger, T., Cortés Donoso, E., Podvin, K., Kulakowski, D., and Bebi, P.: Assessing the interaction between mountain forests and snow avalanches at Nevados de Chillán, Chile and its implications for ecosystem-based disaster risk reduction, Nat. Hazards Earth Syst. Sci., 18, 1173-1186, https://doi.org/10.5194/nhess-18-1173-2018, 2018.

CBD: Connecting Biodiversity And Climate Change Mitigation And Adaption, Report of the Second Ad Hoc Technical Expert Group on Biodiversity and Climate Change, Secretariat of the Convention on Biological Diversity, Montreal, Canada, 2009.

Chan, F. K. S., Griffiths, J. A., Higgitt, D., Xu, S., Zhu, F., Tang, Y. T., Xu, Y., and Thorne, C. R.: "Sponge City" in China - A breakthrough of planning and flood risk management in the urban context, Land Use Policy, 76, 772-778, https://doi.org/10.1016/j.landusepol.2018.03.005, 2018.

Chen, P. Y., Tung, C. P., and Li, Y. H.: Low impact development planning and adaptation decision-making under climate 
change for a community against pluvial flooding, Water, 9, 756, https://doi.org/10.3390/w9100756, 2017.

Cheng, C., Yang, Y. C. E., Ryan, R., Yu, Q., and Brabec, E.: Assessing climate change-induced flooding mitigation for adaptation in Boston's Charles River watershed, USA, Landsc. Urban Plan., 167, 25-36, https://doi.org/10.1016/j.landurbplan.2017.05.019, 2017.

Chou, R.-J.: Achieving Successful River Restoration in Dense Urban Areas: Lessons from Taiwan, Sustainability, 8, 1159, https://doi.org/10.3390/su8111159, 2016.

Chow, J. F., Savić, D., Fortune, D., Kapelan, Z., and Mebrate, N.: Using a systematic, multi-criteria decision support framework to evaluate sustainable drainage designs, Procedia Eng., 70, 343352, https://doi.org/10.1016/j.proeng.2014.02.039, 2014.

Cipolla, S. S., Maglionico, M., and Stojkov, I.: A longterm hydrological modelling of an extensive green roof by means of SWMM, Ecol. Eng., 95, 876-887, https://doi.org/10.1016/j.ecoleng.2016.07.009, 2016.

Climate ADAPT: Climate ADAPT: Sharing Adaption Information Across Europe, available at: https://climate-adapt.eea.europa. eu/, last access: 5 March 2019.

ClimateScan: ClimateScan, available at: https://climatescan.nl/, last access: 25 March 2019.

CNT: National Green Values ${ }^{\mathrm{TM}}$ Calculator Methodology, Center for Neighborhood Technology, Chicago, 2009.

Cohen-Shacham, E., Walters, G., Janzen, C., and Maginnis, C.: Nature-based solutions to address global societal challenges, IUCN Commission on Ecosystem Management (CEM) and IUCN World Commission on Protected Areas (WCPA), Switzerland, 2016.

Dalimunthe, S.: Who Manages Space? Eco-DRR and the Local Community, Sustainability, 10, 1705, https://doi.org/10.3390/su10061705, 2018.

Damodaram, C., Giacomoni, M. H., Prakash Khedun, C., Holmes, H., Ryan, A., Saour, W., and Zechman, E. M.: Simulation of combined best management practices and low impact development for sustainable stormwater management, J. Am. Water Resour. Assoc., 46, 907-918, https://doi.org/10.1111/j.17521688.2010.00462.x, 2010.

de Jesús Arce-Mojica, T., Nehren, U., Sudmeier-Rieux, K., Miranda, P. J., and Anhuf, D.: Nature-based solutions $(\mathrm{NbS})$ for reducing the risk of shallow landslides: Where do we stand?, Int. J. Disast. Risk Reduct., 41, 101293, https://doi.org/10.1016/j.ijdrr.2019.101293, 2019.

Denjean, B., Denjean, B., Altamirano, M. A., Graveline, N., Giordano, R., Van der Keur, P., Moncoulon, D., Weinberg, J., Máñez Costa, M., Kozinc, Z., Mulligan, M., Pengal, P., Matthews, J., van Cauwenbergh, N., López Gunn, E., Bresch, D. N., and Denjean, B.: Natural Assurance Scheme: A level playing field framework for Green-Grey infrastructure development, Environ. Res., 159, 24-38, https://doi.org/10.1016/j.envres.2017.07.006, 2017.

De Risi, R., De Paola, F., Turpie, J., and Kroeger, T.: Life Cycle Cost and Return on Investment as complementary decision variables for urban flood risk management in developing countries, Int. J. Disast. Risk Reduct., 28, 88-106, https://doi.org/10.1016/j.ijdrr.2018.02.026, 2018.

Digman, C. J., Horton, B., Ashley, R. M., and Gill, E.: BeST (Benefits of SuDS Tool) W045d BeST - User Manual, 3rd Edn., ciria, London, UK, 2017.
Dong, X., Guo, H., and Zeng, S.: Enhancing future resilience in urban drainage system: Green versus grey infrastructure, Water Res., 124, 280-289, https://doi.org/10.1016/j.watres.2017.07.038, 2017.

Donnell, E. C. O., Woodhouse, R., and Thorne, C. R.: Evaluating the multiple benefits of a sustainable drainage scheme in Newcastle, UK, Proc. Inst. Civ. Eng. - Water Manage., 171, 191-208, https://doi.org/10.1680/jwama.16.00103, 2018.

DRMKC: European Commission-Disaster Risk Management Knowledge Centre, available at: https://drmkc.jrc.ec.europa.eu/, last access: 25 March 2019.

Duan, H. F., Li, F., and Yan, H.: Multi-Objective Optimal Design of Detention Tanks in the Urban Stormwater Drainage System: LID Implementation and Analysis, Water Resour. Manage., 30, 4635-4648, https://doi.org/10.1007/s11269-016-1444-1, 2016.

Eaton, T. T.: Approach and case-study of green infrastructure screening analysis for urban stormwater control, J. Environ. Manage., 209, 495-504, https://doi.org/10.1016/j.jenvman.2017.12.068, 2018.

EC - European Commission: Nature-Based Solutions and ReNaturing Cities, Final Report of the Horizon 2020 Expert Group on Nature-Based Solutions and Re-Naturing Cities, European Union, Brussels, 2015.

Eckart, K., McPhee, Z., and Bolisetti, T.: Performance and implementation of low impact development A review, Sci. Total Environ., 607-608, 413-432, https://doi.org/10.1016/j.scitotenv.2017.06.254, 2017.

Eggermont, H., Balian, E., Azevedo, J. M. N., Beumer, V., Brodin, T., Claudet, J., Fady, B., Grube, M., Keune, H., Lamarque, P., Reuter, K., Smith, M., Van Ham, C., Weisser, W. W., and Le Roux, X.: Nature-based solutions: New influence for environmental management and research in Europe, Gaia, 24, 243-248, https://doi.org/10.14512/gaia.24.4.9, 2015.

EEA: Exploring nature-based solutions-The role of green infrastructure in mitigating the impacts of weather- and climate change-related natural hazards, EEA Technical report No. 12/2015, Copenhagen, Denmark, 2015.

EEA: Climate change, impacts and vulnerability in Europe 2016An indicator-based report, Report 15/, Climate change adaptation and disaster risk reduction in Europe - Enhancing coherence of the coherence of the knowledge base, Copenhagen, Denmark, 2017.

EKLIPSE: An impact evaluation framework to support planning and evaluation of nature-based solutions projects, Centre for Ecology \& Hydrology, Wallingford, UK, 2017.

Ercolani, G., Antonio, E., Gandolfi, C., Castelli, F., and Masseroni, D.: Evaluating performances of green roofs for stormwater runoff mitigation in a high flood risk urban catchment, J. Hydrol., 566, 830-845, https://doi.org/10.1016/j.jhydrol.2018.09.050, 2018.

Estrella, M. and Saalismaa, N.: Ecosystem-based disaster risk reduction (Eco-DRR): An overview, in: The Role of Ecosystems in Disaster Risk Reduction, edited by: Renaud, F. G., SudmeierRieux, K., and Estrella, M., United Nations University Press, Tokyo, Newyork, Paris, 26-54, 2013.

Estrella, M., Renaud, F. G., and Sudmeier-Rieux, K.: Opportunities, challenges and future perspectives for ecosystem-based disaster risk reduction, in: The Role of Ecosystems in Disaster Risk Reduction, edited by: Renaud, F. G., Sudmeier-Rieux, K., and 
Estrella, M., United Nations University Press, Tokyo, Newyork, Paris, 437-456, 2013.

Faivre, N., Fritz, M., Freitas, T., de Boissezon, B., and Vandewoestijne, S.: Nature-Based Solutions in the EU: Innovating with nature to address social, economic and environmental challenges, Environ. Res., 159, 509-518, https://doi.org/10.1016/j.envres.2017.08.032, 2017.

Faivre, N., Sgobbi, A., Happaerts, S., Raynal, J., and Schmidt, L.: Translating the Sendai Framework into action: The EU approach to ecosystem-based disaster risk reduction, Int. J. Disast. Risk Reduct., 32, 4-10, https://doi.org/10.1016/j.ijdrr.2017.12.015, 2018.

Fenner, R.: Spatial evaluation of multiple benefits to encourage multi-functional design of sustainable drainage in Blue-Green cities, Water, 9, 953, https://doi.org/10.3390/w9120953, 2017.

Fletcher, T. D., Shuster, W., Hunt, W. F., Ashley, R., Butler, D., Arthur, S., Trowsdale, S., Barraud, S., Semadeni-Davies, A., Bertrand-Krajewski, J. L., Mikkelsen, P. S., Rivard, G., Uhl, M., Dagenais, D., and Viklander, M.: SUDS, LID, BMPs, WSUD and more - The evolution and application of terminology surrounding urban drainage, Urban Water J., 12, 525-542, https://doi.org/10.1080/1573062X.2014.916314, 2015.

Fu, J. C., Jang, J. H., Huang, C. M., Lin, W. Y., and Yeh, C. C.: Cross-analysis of land and runoff variations in response to urbanization on basin, watershed, and city scales with/without green infrastructures, Water, 10, 106, https://doi.org/10.3390/w10020106, 2018.

Gao, J., Wang, R., Huang, J., and Liu, M.: Application of BMP to urban runoff control using SUSTAIN model: Case study in an industrial area, Ecol. Model., 318, 177-183, https://doi.org/10.1016/j.ecolmodel.2015.06.018, 2015.

Gedan, K. B., Kirwan, M. L., Wolanski, E., Barbier, E. B., and Silliman, B. R.: The present and future role of coastal wetland vegetation in protecting shorelines: Answering recent challenges to the paradigm, Climatic Change, 106, 7-29, https://doi.org/10.1007/s10584-010-0003-7, 2011.

Giacomoni, M. H. and Joseph, J.: Multi-objective evolutionary optimization and Monte Carlo simulation for placement of low impact development in the catchment scale, J. Water Resour. Plan. Manage., 143, 04017053, https://doi.org/10.1061/(ASCE)WR.1943-5452.0000812, 2017.

Giacomoni, M. H., Zechman, E. M., and Brumbelow, K.: Hydrologic footprint residence: Environmentally friendly criteria for best management practices, J. Hydrol. Eng., 17, 99-108, https://doi.org/10.1061/(ASCE)HE.1943-5584.0000407, 2012.

Goncalves, M. L. R., Zischg, J., Rau, S., Sitzmann, M., and Rauch, W.: Modeling the Effects of Introducing Low Impact Development in a Tropical City: A Case Study from Joinville, Brazil, Sustainability, 10, 728, https://doi.org/10.3390/su10030728, 2018.

Herrera, J., Bonilla, C. A., Castro, L., Vera, S., Reyes, R., and Gironás, J.: A model for simulating the performance and irrigation of green stormwater facilities at residential scales in semiarid and Mediterranean regions, Environ. Model. Softw., 95, 246257, https://doi.org/10.1016/j.envsoft.2017.06.020, 2017.

Hoang, L., Fenner, R. A., and Skenderian, M.: A conceptual approach for evaluating the multiple benefits of urban flood management practices, J. Flood Risk Manage., 11, S943-S959, https://doi.org/10.1111/jfr3.12267, 2018.
Hu, M., Sayama, T., Zhang, X., Tanaka, K., Takara, K., and Yang, H.: Evaluation of low impact development approach for mitigating flood inundation at a watershed scale in China, J. Environ. Manage., 193, 430-438, https://doi.org/10.1016/j.jenvman.2017.02.020, 2017.

Huang, C., Hsu, N., Liu, H., and Huang, Y.: Optimization of low impact development layout designs for megacity fl ood mitigation, J. Hydrol., 564, 542-558, https://doi.org/10.1016/j.jhydrol.2018.07.044, 2018.

Huang, J. J., Li, Y., Niu, S., and Zhou, S. H.: Assessing the performances of low impact development alternatives by long-term simulation for a semi-arid area in Tianjin, Northern China, Water Sci. Technol., 70, 1740-1745, https://doi.org/10.2166/wst.2014.228, 2014.

Ishimatsu, K., Ito, K., Mitani, Y., Tanaka, Y., Sugahara, T., and Naka, Y: Use of rain gardens for stormwater management in urban design and planning, Landsc. Ecol. Eng., 13, 205-212, https://doi.org/10.1007/s11355-016-0309-3, 2017.

Jayasooriya, V. M. and Ng, A. W. M.: Tools for modeling of stormwater management and economics of green infrastructure practices: A review, Water Air. Soil Pollut., 225, 2055, https://doi.org/10.1007/s11270-014-2055-1, 2014.

Jia, H., Yao, H., Tang, Y., Yu, S. L., Field, R., and Tafuri, A. N.: LID-BMPs planning for urban runoff control and the case study in China, J. Environ. Manage., 149, 65-76, https://doi.org/10.1016/j.jenvman.2014.10.003, 2015.

Joyce, J., Chang, N., Harji, R., Ruppert, T., and Imen, S.: Developing a multi-scale modeling system for resilience assessment of green-grey drainage infrastructures under climate change and sea level rise impact, Environ. Model. Softw., 90, 1-26, https://doi.org/10.1016/j.envsoft.2016.11.026, 2017.

Kabisch, N., Frantzeskaki, N., Pauleit, S., Naumann, S., Davis, M., Artmann, M., Haase, D., Knapp, S., Korn, H., Stadler, J., Zaunberger, K., and Bonn, A.: Nature-based solutions to climate change mitigation and adaptation in urban areas: perspectives on indicators, knowledge gaps, barriers, and opportunities for action, Ecol. Soc., 21, 39, https://doi.org/10.5751/ES-08373210239, 2016.

Karamouz, M. and Nazif, S.: Reliability-Based Flood Management in Urban Watersheds Considering Climate Change Impacts, J. Water Resour. Plan. Manage., 139, 520-533, https://doi.org/10.1061/(ASCE)WR.1943-5452.0000345, 2013.

Keesstra, S., Nunes, J., Novara, A., Finger, D., Avelar, D., Kalantari, Z., and Cerdà, A.: The superior effect of nature based solutions in land management for enhancing ecosystem services, Sci. Total Environ., 610-611, 997-1009, https://doi.org/10.1016/j.scitotenv.2017.08.077, 2018.

Khan, U. T., Valeo, C., Chu, A., and He, J.: A data driven approach to bioretention cell performance: Prediction and design, Water, 5, 13-28, https://doi.org/10.3390/w5010013, 2013.

Khastagir, A. and Jayasuriya, L. N. N.: Impacts of using rainwater tanks on stormwater harvesting and runoff quality, Water Sci. Technol., 62, 324-329, https://doi.org/10.2166/wst.2010.283, 2010.

Klijn, F., de Bruin, D., de Hoog, M. C., Jansen, S., and Sijmons, D. F.: Design quality of room-for-the-river measures in the Netherlands: role and assessment of the quality team (Q-team), Int. J. River Basin Manage., 11, 287-299, https://doi.org/10.1080/15715124.2013.811418, 2013. 
Kuller, M., Farrelly, M., Deletic, A., and Bach, P. M.: Building effective Planning Support Systems for green urban water infrastructure - Practitioners' perceptions, Environ. Sci. Policy, 89, 153-162, https://doi.org/10.1016/j.envsci.2018.06.011, 2018.

Lafortezza, R., Chen, J., van den Bosch, C. K., and Randrup, T. B.: Nature-based solutions for resilient landscapes and cities, Environ. Res., 165, 431-441, https://doi.org/10.1016/j.envres.2017.11.038, 2018.

Lawson, E., Thorne, C., Ahilan, S., Allen, D., Arthur, S., Everett, G., Fenner, R., Glenis, V., Guan, D., Hoang, L., Kilsby, C., Lamond, J., Mant, J., Maskrey, S., Mount, N., Sleigh, A., Smith, L., and Wright, N.: Delivering and evaluating the multiple flood risk benefits in Blue-Green cities: An interdisciplinary approach, WIT Trans. Ecol. Environ., 184, 113-124, https://doi.org/10.2495/FRIAR140101, 2014.

Lee, J. Y., Moon, H. J., Kim, T. I., Kim, H. W., and Han, M. Y.: Quantitative analysis on the urban flood mitigation effect by the extensive green roof system, Environ. Pollut., 181, 257-261, https://doi.org/10.1016/j.envpol.2013.06.039, 2013.

Lennon, M., Scott, M., and O'Neill, E.: Urban Design and Adapting to Flood Risk: The Role of Green Infrastructure, J. Urban Des., 19, 745-758, https://doi.org/10.1080/13574809.2014.944113, 2014.

Leslie, S., John, R. J., Khalid, A., Jenny, X. Z., Sabu, P., and Teresa, R.: SUSTAIN - A Framework for Placement of Best Management Practices in Urban Watersheds to Protect Water Quality, Environmental Protection Agency, Washington, D.C., 2009.

Li, C., Liu, M., Hu, Y., Han, R., Shi, T., Qu, X., and Wu, Y.: Evaluating the hydrologic performance of low impact development scenarios in a micro Urban catchment, Int. J. Environ. Res. Publ. Health, 15, 273, https://doi.org/10.3390/ijerph15020273, 2018.

Li, J., Deng, C., Li, H., Ma, M., and Li, Y.: Hydrological Environmental Responses of LID and Approach for Rainfall Pattern Selection in Precipitation Data-Lacked Region, Water Resour. Manage., 32, 3271-3284, https://doi.org/10.1007/s11269018-1990-9, 2018.

Li, N., Qin, C., and Du, P.: Optimization of China Sponge City Design: The Case of Lincang Technology Innovation Park, Water, 10, 1189, https://doi.org/10.3390/w10091189, 2018.

Liao, Z. L., Zhang, G. Q., Wu, Z. H., He, Y., and Chen, H.: Combined sewer overflow control with LID based on SWMM: An example in Shanghai, China, Water Sci. Technol., 71, 1136-1142, https://doi.org/10.2166/wst.2015.076, 2015.

Liew, Y. S., Selamat, Z., Ghani, A. A., and Zakaria, N. A.: Performance of a dry detention pond: Case study of Kota Damansara, Selangor, Malaysia, Urban Water J., 9, 129-136, https://doi.org/10.1080/1573062X.2011.644567, 2012.

Liu, L. and Jensen, M. B.: Green infrastructure for sustainable urban water management: Practices of five forerunner cities, Cities, 74, 126-133, https://doi.org/10.1016/j.cities.2017.11.013, 2018.

Liu, Y., Bralts, V. F., and Engel, B. A.: Evaluating the effectiveness of management practices on hydrology and water quality at watershed scale with a rainfall-runoff model, Sci. Total Environ., 511, 298-308, https://doi.org/10.1016/j.scitotenv.2014.12.077, 2015.

Liu, Y., Theller, L. O., Pijanowski, B. C., and Engel, B. A.: Optimal selection and placement of green infrastructure to reduce impacts of land use change and climate change on hydrology and water quality: An application to the Trail
Creek Watershed, Indiana, Sci. Total Environ., 553, 149-163, https://doi.org/10.1016/j.scitotenv.2016.02.116, 2016.

Liu, Y., Engel, B. A., Flanagan, D. C., Gitau, M. W., McMillan, S. K., and Chaubey, I.: A review on effectiveness of best management practices in improving hydrology and water quality: Needs and opportunities, Sci. Total Environ., 601-602, 580-593, https://doi.org/10.1016/j.scitotenv.2017.05.212, 2017.

Loc, H. H., Duyen, P. M., Ballatore, T. J., Lan, N. H. M., and Das Gupta, A.: Applicability of sustainable urban drainage systems: an evaluation by multi-criteria analysis, Environ. Syst. Decis., 37, 332-343, https://doi.org/10.1007/s10669-017-96394, 2017.

Loos, J. R. and Rogers, S. H.: Understanding stakeholder preferences for flood adaptation alternatives with natural capital implications, Ecol. Soc., 21, 32, https://doi.org/10.5751/ES-08680210332, 2016.

Loperfido, J. V., Noe, G. B., Jarnagin, S. T., and Hogan, D. M.: Effects of distributed and centralized stormwater best management practices and land cover on urban stream hydrology at the catchment scale, J. Hydrol., 519, 2584-2595, https://doi.org/10.1016/j.jhydrol.2014.07.007, 2014.

Lottering, N., du Plessis, D., and Donaldson, R.: Coping with drought: The experience of water sensitive urban design (WSUD) in the George Municipality, Water SA, 41, 1-8, https://doi.org/10.4314/wsa.v41i1.1, 2015.

Luan, Q., Fu, X., Song, C., Wang, H., Liu, J., and Wang, Y.: Runoff effect evaluation of LID through SWMM in typical mountainous, low-lying urban areas: A case study in China, Water, 9, 439, https://doi.org/10.3390/w9060439, 2017.

MacKinnon, K., Sobrevila, C., and Hickey, V.: Biodiversity, Climate Change and Adaptation: Nature-Based Solutions from the World Bank Portfolio, Washington, D.C., 2008.

Majidi, A. N., Vojinovic, Z., Alves, A., Weesakul, S., Sanchez, A., Boogaard, F., and Kluck, J.: Planning Nature-Based Solutions for Urban Flood Reduction and Thermal Comfort Enhancement, Sustainability, 11, 6361, https://doi.org/10.3390/su11226361, 2019.

Maragno, D., Gaglio, M., Robbi, M., Appiotti, F., Fano, E. A., and Gissi, E.: Fine-scale analysis of urban flooding reduction from green infrastructure: An ecosystem services approach for the management of water flows, Ecol. Model., 386, 1-10, https://doi.org/10.1016/j.ecolmodel.2018.08.002, 2018.

Matthews, T., Lo, A. Y., and Byrne, J. A.: Reconceptualizing green infrastructure for climate change adaptation: Barriers to adoption and drivers for uptake by spatial planners, Landsc. Urban Plan., 138, 155-163, https://doi.org/10.1016/j.landurbplan.2015.02.010, 2015.

McVittie, A., Cole, L., Wreford, A., Sgobbi, A., and Yordi, B.: Ecosystem-based solutions for disaster risk reduction: Lessons from European applications of ecosystem-based adaptation measures, Int. J. Disast. Risk Reduct., 32, 42-54, https://doi.org/10.1016/j.ijdrr.2017.12.014, 2018.

Mei, C., Liu, J., Wang, H., Yang, Z., Ding, X., and Shao, W.: Integrated assessments of green infrastructure for fl ood mitigation to support robust decision-making for sponge city construction in an urbanized watershed, Sci. Total Environ., 639, 1394-1407, https://doi.org/10.1016/j.scitotenv.2018.05.199, 2018.

Merz, B., Kreibich, H., Schwarze, R., and Thieken, A.: Review article "Assessment of economic flood damage", Nat. Hazards 
Earth Syst. Sci., 10, 1697-1724, https://doi.org/10.5194/nhess10-1697-2010, 2010.

Mills, G., Anjos, M., Brennan, M., Williams, J., McAleavey, C., and Ningal, T.: The green 'signature' of Irish cities: An examination of the ecosystem services provided by trees using i-Tree Canopy software, Irish Geogr., 48, 62-77, 2016.

Naturally Resilient Communities: Naturally Resilient Communities solutions, available at: http://nrcsolutions.org/strategies/ \#solutions, last access: 1 February 2019.

Nature-based Solutions Initiative: Nature-Based Solutions Policy Platform, available at: http://nbspolicyplatform.org/, last access: 5 March 2019.

nature4cities: European Horizon 2020 NBS project, available at: https://www.nature4cities.eu/h2020-nbs-projects, last access: 11 February 2019.

Nature of Cities: The Nature of Cities, available at: https://www. thenatureofcities.com/, last access: 5 March 2019.

NATURVATION: Urban Nature Atlas | NATURVATION, available at: https://naturvation.eu/atlas, last access: 5 March 2019.

Naumann, S., McKenna, D., Kaphengst, T., Pieterse, M., Rayment, M., and Davis, M.: Design, implementation and cost elements of Green Infrastructure projects, Final report to the European Commission, DG Environment, 2011.

Nesshöver, C., Assmuth, T., Irvine, K. N., Rusch, G. M., Waylen, K. A., Delbaere, B., Haase, D., Jones-Walters, L., Keune, H., Kovacs, E., Krauze, K., Külvik, M., Rey, F., van Dijk, J., Vistad, O. I., Wilkinson, M. E., and Wittmer, H.: The science, policy and practice of nature-based solutions: An interdisciplinary perspective, Sci. Total Environ., 579, 1215-1227, https://doi.org/10.1016/j.scitotenv.2016.11.106, 2017.

Nordman, E. E., Isely, E., Isely, P., and Denning, R.: Benefitcost analysis of stormwater green infrastructure practices for Grand Rapids, Michigan, USA, J. Clean. Prod., 200, 501-510, https://doi.org/10.1016/j.jclepro.2018.07.152, 2018.

NWRM: Natural Water Retention Measures, available at: http:// nwrm.eu/, last access: 1 March 2019.

Olszewski, J. M. and Allen, P. D.: Comparing the Hydrologic Performance of a Bioretention Cell with Predevelopment Values, J. Irrig. Drain. Eng., 1, 124-130, https://doi.org/10.1061/(ASCE)IR.1943-4774.0000504, 2013.

Onuma, A. and Tsuge, T.: Comparing green infrastructure as ecosystem-based disaster risk reduction with gray infrastructure in terms of costs and benefits under uncertainty: A theoretical approach, Int. J. Disast. Risk Reduct., 32, 22-28, https://doi.org/10.1016/j.ijdrr.2018.01.025, 2018.

Oppla: Natural capital Ecosystem services Nature-based solutions | Oppla, available at: https://oppla.eu/, last access: 25 March 2019.

Oraei Zare, S., Saghafian, B., and Shamsai, A.: Multiobjective optimization for combined quality-quantity urban runoff control, Hydrol. Earth Syst. Sci., 16, 4531-4542, https://doi.org/10.5194/hess-16-4531-2012, 2012.

Ossa-Moreno, J., Smith, K. M., and Mijic, A.: Economic analysis of wider benefits to facilitate $\mathrm{SuDS}$ uptake in London, UK, Sustain. Cities Soc., 28, 411-419, https://doi.org/10.1016/j.scs.2016.10.002, 2017.

Pagano, A., Pluchinotta, I., Pengal, P., Cokan, B., and Giordano, R.: Engaging stakeholders in the assessment of NBS effectiveness in flood risk reduction: A participatory System Dynamics Model for benefits and co-benefits evaluation, Sci. Total Environ., 690, 543-555, https://doi.org/10.1016/j.scitotenv.2019.07.059, 2019.

PANORAMA: PANORAMA slutions for a healthy planet, available at: https://panorama.solutions, last access: 9 July 2019.

Pappalardo, V., La Rosa, D., Campisano, A., and La Greca, P.: The potential of green infrastructure application in urban runoff control for land use planning: A preliminary evaluation from a southern Italy case study, Ecosyst. Serv., 26, 345-354, https://doi.org/10.1016/j.ecoser.2017.04.015, 2017.

PEARL: PEARL | Preparing for Extreme And Rare events in coastaL regions, available at: http://www.pearl-fp7.eu/ (last access: 25 November 2018), 2019.

PEDRR: Partnership for Environment and Disaster Risk Reduction, available at: http://pedrr.org/, last access: 5 July 2019.

Petit-Boix, A., Sevigné-Itoiz, E., Rojas-Gutierrez, L. A., Barbassa, A. P., Josa, A., Rieradevall, J., and Gabarrell, X.: Floods and consequential life cycle assessment: Integrating flood damage into the environmental assessment of stormwater Best Management Practices, J. Clean. Prod., 162, 601-608, https://doi.org/10.1016/j.jclepro.2017.06.047, 2017.

Qin, H., Li, Z., and Fu, G.: The effects of low impact development on urban flooding under different rainfall characteristics, J. Environ. Manage., 129, 577-585, https://doi.org/10.1016/j.jenvman.2013.08.026, 2013.

Radonic, L.: Re-conceptualising Water Conservation: Rainwater Harvesting in the Desert of the Southwestern United States, Water Altern., 12, 699-714, 2019.

Rangarajan, S., Marton, D., Montalto, F., Cheng, Z. J., and Smith, G.: Measuring the flow: Green infrastructure grows in Brooklyn, Curr. Opin. Environ. Sustain., 17, 36-41, https://doi.org/10.1016/j.cosust.2015.09.001, 2015.

Raymond, C. M., Frantzeskaki, N., Kabisch, N., Berry, P., Breil, M., Nita, M. R., Geneletti, D., and Calfapietra, C.: A framework for assessing and implementing the co-benefits of naturebased solutions in urban areas, Environ. Sci. Policy, 77, 15-24, https://doi.org/10.1016/j.envsci.2017.07.008, 2017.

Reguero, B. G., Beck, M. W., Bresch, D. N., Calil, J., and Meliane, I.: Comparing the cost effectiveness of naturebased and coastal adaptation: A case study from the Gulf Coast of the United States, PLoS One, 13, 1-24, https://doi.org/10.1371/journal.pone.0192132, 2018.

Reynaud, A., Lanzanova, D., Liquete, C., and Grizzetti, B.: Going green? Ex-post valuation of a multipurpose water infrastructure in Northern Italy, Ecosyst. Serv., 27, 70-81, https://doi.org/10.1016/j.ecoser.2017.07.015, 2017.

Romnée, A. and De Herde, A.: Hydrological efficiency evaluation tool of urban Stormwater best management practices, Int. J. Sustain. Dev. Plan., 10, 435-452, https://doi.org/10.2495/SDP-V10N4-435-452, 2015.

Rozos, E., Makropoulos, C., and Maksimovic, C.: Rethinking urban areas: an example of an integrated blue-green approach, Water Sci. Technol. Water Supply, 13, 1534-1542, https://doi.org/10.2166/ws.2013.140, 2013.

Ruckelshaus, M. H., Guannel, G., Arkema, K., Verutes, G., Griffin, R., Guerry, A., Silver, J., Faries, J., Brenner, J., and Rosenthal, A.: Evaluating the Benefits of Green Infrastructure for Coastal Areas: Location, Location, Location, Coast. Manage., 44, 504516, https://doi.org/10.1080/08920753.2016.1208882, 2016. 
Sahani, J., Kumar, P., Debele, S., Spyrou, C., Loupis, M., Aragão, L., Porcù, F., Shah, M. A. R., and Di Sabatino, S.: Hydro-meteorological risk assessment methods and management by nature-based solutions, Sci. Total Environ., 696, 133936, https://doi.org/10.1016/j.scitotenv.2019.133936, 2019.

Santoro, S., Pluchinotta, I., Pagano, A., Pengal, P., Cokan, B., and Giordano, R.: Assessing stakeholders' risk perception to promote Nature Based Solutions as flood protection strategies: The case of the Glinščica river (Slovenia), Sci. Total Environ., 655, 188201, https://doi.org/10.1016/j.scitotenv.2018.11.116, 2019.

Scarano, F. R.: Ecosystem-based adaptation to climate change: concept, scalability and a role for conservation science, Perspect. Ecol. Conserv., 15, 65-73, https://doi.org/10.1016/j.pecon.2017.05.003, 2017.

Schifman, L. A., Herrmann, D. L., Shuster, W. D., Ossola, A., Garmestani, A., and Hopton, M. E.: Situating Green Infrastructure in Context: A Framework for Adaptive SocioHydrology in Cities, Water Resour. Res., 53, 10139-10154, https://doi.org/10.1002/2017WR020926, 2017.

Schoonees, T., Gijón Mancheño, A., Scheres, B., Bouma, T. J., Silva, R., Schlurmann, T., and Schüttrumpf, H.: Hard Structures for Coastal Protection, Towards Greener Designs, Estuar. Coast., 42, 1709-1729, https://doi.org/10.1007/s12237019-00551-z, 2019.

Schubert, J. E., Burns, M. J., Fletcher, T. D., and Sanders, B. F.: A framework for the case-specific assessment of Green Infrastructure in mitigating urban flood hazards, Adv. Water Resour., 108, 55-68, https://doi.org/10.1016/j.advwatres.2017.07.009, 2017.

SEI: Stockholm Environment Institute: weADAPT | Climate adaptation planning, research and practice, available at: https://www. weadapt.org/, last access: 5 March 2019.

Seifollahi-Aghmiuni, S., Nockrach, M., and Kalantari, Z.: The potential of wetlands in achieving the sustainable development goals of the 2030 Agenda, Water, 11, 1-14, https://doi.org/10.3390/w11030609, 2019.

Semadeni-Davies, A., Hernebring, C., Svensson, G., and Gustafsson, L. G.: The impacts of climate change and urbanisation on drainage in Helsingborg, Sweden: Suburban stormwater, J. Hydrol., 350, 114-125, https://doi.org/10.1016/j.jhydrol.2007.11.006, 2008.

Shafique, M. and Kim, R.: Recent progress in low-impact development in South Korea: Water-management policies, challenges and opportunities, Water, 10, 435, https://doi.org/10.3390/w10040435, 2018.

Shafique, M., Kim, R., and Kyung-Ho, K.: Rainfall runoff mitigation by retrofitted permeable pavement in an urban area, Sustainability, 10, 1-10, https://doi.org/10.3390/su10041231, 2018.

Soares, A. L., Rego, F. C., McPherson, E. G., Simpson, J. R., Peper, P. J., and Xiao, Q.: Benefits and costs of street trees in Lisbon, Portugal, Urban For. Urban Green., 10, 69-78, https://doi.org/10.1016/j.ufug.2010.12.001, 2011.

Song, K., You, S., and Chon, J.: Simulation modeling for a resilience improvement plan for natural disasters in a coastal area, Environ. Pollut., 242, 1970-1980, https://doi.org/10.1016/j.envpol.2018.07.057, 2018.

Strecker, E. W., Quigley, M. M., Urbonas, B. R., Jones, J. E., and Clary, J. K.: Determining Urban Storm Water BMP Effectiveness, J. Water Resour. Plan. Manage., 127, 144-149,
https://doi.org/10.1061/(ASCE)0733-9496(2001)127:3(144), 2001.

Sutton-Grier, A. E., Gittman, R. K., Arkema, K. K., Bennett, R. O., Benoit, J., Blitch, S., Burks-Copes, K. A., Colden, A., Dausman, A., DeAngelis, B. M., Hughes, A. R., Scyphers, S. B., and Grabowski, J. H.: Investing in natural and nature-based infrastructure: Building better along our coasts, Sustainability, 10, 111, https://doi.org/10.3390/su10020523, 2018.

Tao, J., Li, Z., Peng, X., and Ying, G.: Quantitative analysis of impact of green stormwater infrastructures on combined sewer overflow control and urban flooding control, Front. Environ. Sci. Eng., 11, 1-12, https://doi.org/10.1007/s11783-017-0952-4, 2017.

ThinkNature: ThinkNature | Platform for Nature-Based Solutions, available at: https://www.think-nature.eu/, last access: 5 March 2019.

Thorne, C. R., Lawson, E. C., Ozawa, C., Hamlin, S. L., and Smith, L. A.: Overcoming uncertainty and barriers to adoption of Blue-Green Infrastructure for urban flood risk management, J. Flood Risk Manage., 11, S960-S972, https://doi.org/10.1111/jfr3.12218, 2018.

Thorslund, J., Jarsjo, J., Jaramillo, F., Jawitz, J. W., Manzoni, S., Basu, N. B., Chalov, S. R., Cohen, M. J., Creed, I. F., Goldenberg, R., Hylin, A., Kalantari, Z., Koussis, A. D., Lyon, S. W., Mazi, K., Mard, J., Persson, K., Pietro, J., Prieto, C., Quin, A., Van Meter, K., and Destouni, G.: Wetlands as large-scale nature-based solutions: Status and challenges for research, engineering and management, Ecol. Eng., 108, 489-497, https://doi.org/10.1016/j.ecoleng.2017.07.012, 2017.

Triyanti, A. and Chu, E.: A survey of governance approaches to ecosystem-based disaster risk reduction: Current gaps and future directions, Int. J. Disast. Risk Reduct., 32, 11-21, https://doi.org/10.1016/j.ijdrr.2017.11.005, 2018.

Van Coppenolle, R., Schwarz, C., and Temmerman, S.: Contribution of Mangroves and Salt Marshes to Nature-Based Mitigation of Coastal Flood Risks in Major Deltas of the World, Estuar. Coasts, 41, 1699-1711, https://doi.org/10.1007/s12237018-0394-7, 2018.

Vogel, J. R., Moore, T. L., Coffman, R. R., Rodie, S. N., Hutchinson, S. L., McDonough, K. R., McLemore, A. J., and McMaine, J. T.: Critical Review of Technical Questions Facing Low Impact Development and Green Infrastructure: A Perspective from the Great Plains, Water Environ. Res., 87, 849-862, https://doi.org/10.2175/106143015X14362865226392, 2015.

Vojinovic, Z., Keerakamolchai, W., Weesakul, S., Pudar, R., Medina, N., and Alves, A.: Combining Ecosystem Services with Cost-Benefit Analysis for Selection of Green and Grey Infrastructure for Flood Protection in a Cultural Setting, Environments, 4, 3, https://doi.org/10.3390/environments4010003, 2017.

Voskamp, I. M. and Van de Ven, F. H. M.: Planning support system for climate adaptation: Composing effective sets of blue-green measures to reduce urban vulnerability to extreme weather events, Build. Environ., 83, 159-167, https://doi.org/10.1016/j.buildenv.2014.07.018, 2015.

Wang, Q., Guidolin, M., Savic, D., and Kapelan, Z.: TwoObjective Design of Benchmark Problems of a Water Distribution System via MOEAs: Towards the Best-Known Approximation of the True Pareto Front, J. Water Resour. Plan. Man- 
age., 141, 04014060, https://doi.org/10.1061/(ASCE)WR.19435452.0000460, 2015.

Wang, Y., Huang, J., and Chen, X.: Do forests relieve crop thirst in the face of drought? Empirical evidence from South China, Global Environ. Change, 55, 105-114, https://doi.org/10.1016/j.gloenvcha.2019.01.008, 2019.

Watson, K. B., Ricketts, T., Galford, G., Polasky, S., and O'Niel-Dunne, J.: Quantifying flood mitigation services: The economic value of Otter Creek wetlands and floodplains to Middlebury, VT, Ecol. Econ., 130, 16-24, https://doi.org/10.1016/j.ecolecon.2016.05.015, 2016.

Webber, J. L., Fu, G., and Butler, D.: Rapid surface water intervention performance comparison for urban planning, Water Sci. Technol., 77, 2084-2092, https://doi.org/10.2166/wst.2018.122, 2018.

Wheeler, B. W., Cooper, A. R., Page, A. S., and Jago, R.: Greenspace and children's physical activity: A GPS/GIS analysis of the PEACH project, Prev. Med. (Baltim.), 51, 148-152, https://doi.org/10.1016/j.ypmed.2010.06.001, 2010.

Whelans consultants, Hawthorn, M., and Thompson, P.: Planning \& management guidelines for water sensitive urban (residential) design: consultants report prepared for the Department of Planning and Urban Development, State Planning Commission, Perth, Australia, 1994.

World Bank, GFDRR, and Deltares: Natural Hazards - Naturebased Solutions, available at: https://naturebasedsolutions.org/, last access: 5 March 2019.

Woznicki, S. A., Hondula, K. L., and Jarnagin, S. T.: Effectiveness of landscape-based green infrastructure for stormwater management in suburban catchments, Hydrol. Process., 32, 2346-2361, https://doi.org/10.1002/hyp.13144, 2018.
Wu, J., Yang, R., and Song, J.: Effectiveness of low-impact development for urban inundation risk mitigation under different scenarios: A case study in Shenzhen, China, Nat. Hazards Earth Syst. Sci., 18, 2525-2536, https://doi.org/10.5194/nhess18-2525-2018, 2018.

Yang, Y., Fong, T., and Chui, M.: Integrated hydroenvironmental impact assessment and alternative selection of low impact development practices in small urban catchments, J. Environ. Manage., 223, 324-337, https://doi.org/10.1016/j.jenvman.2018.06.021, 2018.

Yazdi, J. and Salehi Neyshabouri, S. A. A.: Identifying low impact development strategies for flood mitigation using a fuzzyprobabilistic approach, Environ. Model. Softw., 60, 31-44, https://doi.org/10.1016/j.envsoft.2014.06.004, 2014.

Zhang, K. and Chui, T. F. M.: A comprehensive review of spatial allocation of LID-BMP-GI practices: Strategies and optimization tools, Sci. Total Environ., 621, 915-929, https://doi.org/10.1016/j.scitotenv.2017.11.281, 2018.

Zhang, K. and Chui, T. F. M.: Linking hydrological and bioecological benefits of green infrastructures across spatial scales - A literature review, Sci. Total Environ., 646, 1219-1231, https://doi.org/10.1016/j.scitotenv.2018.07.355, 2019.

Zhu, Z. and Chen, X.: Evaluating the effects of low impact development practices on urban flooding under different rainfall intensities, Water, 9, 548, https://doi.org/10.3390/w9070548, 2017.

Zölch, T., Henze, L., Keilholz, P., and Pauleit, S.: Regulating urban surface runoff through nature-based solutions - An assessment at the micro-scale, Environ. Res., 157, 135-144, https://doi.org/10.1016/j.envres.2017.05.023, 2017 